\title{
A governance analysis of Ningaloo and Shark Bay Marine Parks, Western Australia: putting the 'eco' in tourism to build resilience but threatened in long-term by climate change?
}

\author{
Peter J.S. Jones ${ }^{1,2}$ \\ 1. Reader in Environmental Governance, Department of Geography, University College London, Pearson \\ Building, Gower Street, London WC1E 6BT, UK, P.J.Jones@ucl.ac.uk \\ 2. Adjunct Research Fellow, UWA School of Agriculture and Environment, University of Western Australia, 35 \\ Stirling Highway, Crawley, WA 6009, Australia
}

\begin{abstract}
The governance frameworks for Ningaloo Marine Park (NMP) and Shark Bay Marine Park (SBMP) are explored, employing the MPA governance analysis framework. Both face similar conflicts typical of ecotourism, particularly related to the impacts of recreational fishing and marine wildlife tourism. A high diversity of incentives is found to be used, the combination of which promotes effectiveness in achieving conservation objectives and equity in governance. Highly evolved regulations have provided for depleted spangled emperor (Lethrinus nebulosus) stocks in NMP to stabilise and begin recovery, and pink snapper (Pagrus auratus) stocks in SBMP to recover from past depletions, though there are still concerns about recreational fishing impacts. The governance frameworks for marine wildlife tourism are considered extremely good practice. Some incentives need strengthening in both cases, particularly capacity for enforcement, penalties for deterrence and cross-jurisdictional coordination. In NMP there was also a need to promote transparency in making research and monitoring results available, and to address tensions with the recreational fishing sector by building linkages to provide for their specific representation, as part of a strategy to build trust and cooperation with this sector. Both case studies represent world-leading good practice in addressing proximal impacts from local activities, but in the longer-term the foundation species of both marine parks are critically threatened by the distal impacts of climate change. A diversity of incentives has promoted resilience in the short-term, but global action to mitigate climate change is the only way to promote the long-term resilience of these iconic marine ecosystems.
\end{abstract}

Keywords: governance; effectiveness; equity; resilience; climate change; ecotourism

\section{Highlights}

$>$ Recreational fishing and marine wildlife tourism are the main conflicts;

$>$ Both marine parks are leading examples of good practice in mitigating conflicts;

$>$ A high diversity of interacting incentives helps mitigate proximal impacts;

$>$ Several incentives are in need of strengthening to improve governance;

$>$ Mitigating the distal impacts of climate change is essential in long term.

This is the authors' version of the final accepted Marine Policy manuscript. Elsevier@ 2019. This manuscript version is made available under the CC-BY-NC-ND 4.0 license. DOI:10.1016/j.marpol.2019.103636 


\section{Introduction}

There is much attention to studies of the Great Barrier Reef Marine Park, including its successes as an example of good practice of effective governance [1], along with the major challenges it is currently facing $[2,3]$. This paper focuses on Australia's two other mainland marine World Heritage Sites (WHSs): Ningaloo Marine Park (NMP) and Shark Bay Marine Park (SBMP) (Figure 1, Table 1), each of the marine parks forming the main marine component of these WHSs.

\begin{tabular}{|l|l|l|}
\hline MPA & Ningaloo Marine Park (NMP) & Shark Bay Marine Park (SBMP) \\
\hline Area & $2,633 \mathrm{~km}^{2}$ & $7,487 \mathrm{~km}^{2}$ \\
\hline Year of designation & $1987($ WHS in 2011) & $1990($ WHS in 1991) \\
\hline
\end{tabular}

Table 1 The two MPA Case studies

The Marine Protected Area Governance (MPAG) analytical framework [4] is employed to deconstruct and analyse the governance of these two MPAs. This draws on the findings from semi-structured interviews with various users, regulators and researchers and non-participant observations of meetings, initially undertaken April-May 2015 but with some subsequent interviews, coupled with document analyses of management plans, monitoring reports, etc., including recent updates. This research was undertaken in keeping with University College London's research ethics requirements under procedures approved by the Research Ethics Committee of the University of Western Australia (RA/4/1/7395). The findings will be discussed under the following headings: 2. Context; 3. Objectives; 4. Drivers/conflicts; 5 . Governance approach; 6 . Effectiveness; 7. Incentives; 8. Discussions; 9. Conclusions. The perspectives and views reported will be anonymised, in that they will not be attributed to any specific individual or category of interviewees, in order to maintain confidentiality on some potentially sensitive issues, in keeping with research ethics requirements. This is one of several case study papers in a special section of Marine Policy on MPA governance case studies [5], employing the same framework and methods. 


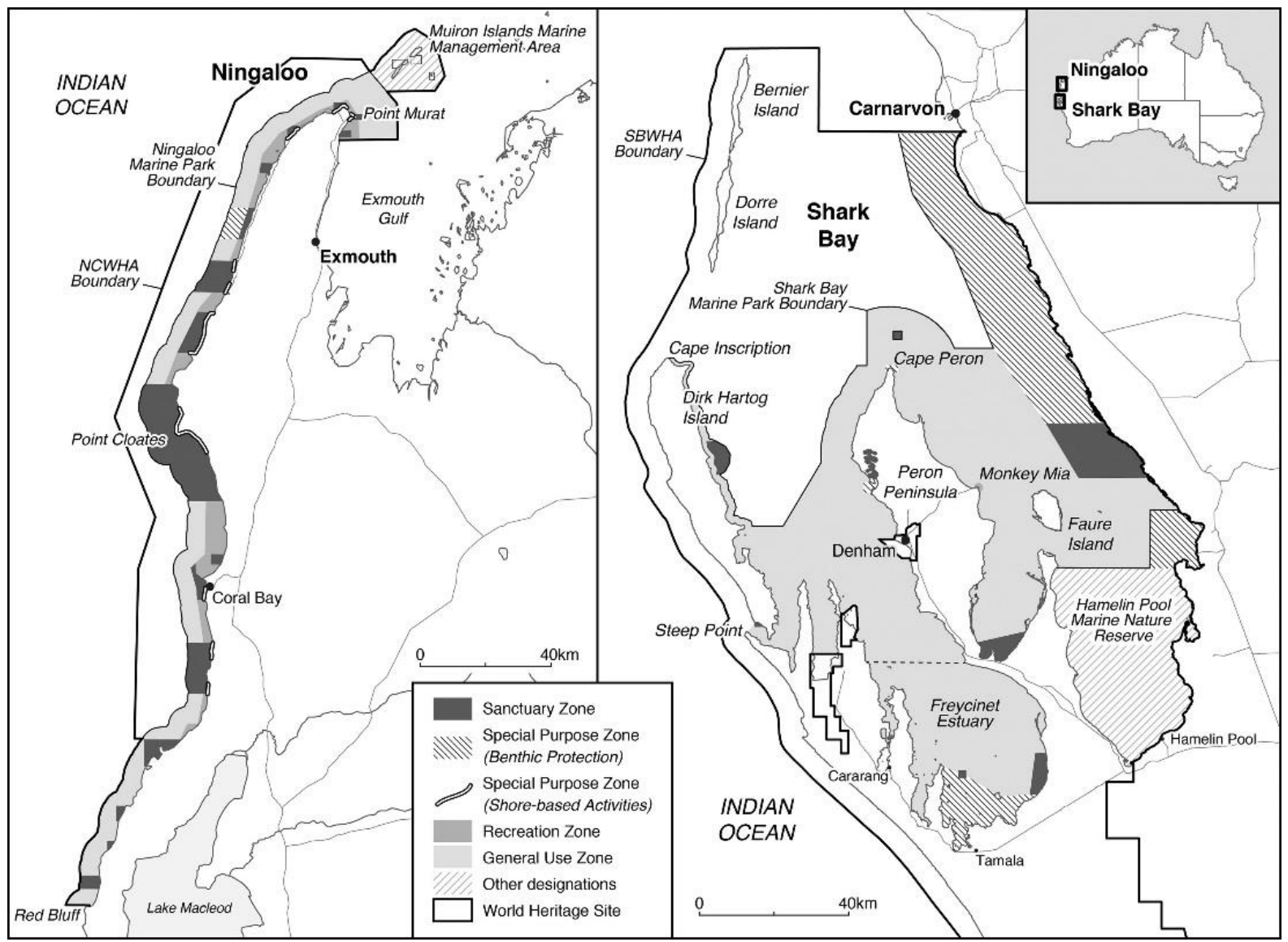

Figure 1 Location and zonation schemes for (a) Ningaloo Marine Park and (b) Shark Bay Marine Park (Adapted from PaWS maps)

\section{Context}

Australia is a commonwealth country with a federal parliament and six states, and has a relatively well developed economy (Table 2).

\begin{tabular}{|l|l|l|l|}
\hline GDP Per Capita & $\begin{array}{l}\text { US\$49,600 (2016, } \\
29 / 229)[6]\end{array}$ & State Capacity & $\begin{array}{l}1.54 \text { (rank 92.4\%, 2016) } \\
{[7]}\end{array}$ \\
\hline GDP Growth Rate & $2.5 \%(2016)[6]$ & Human Development Index & $0.935(2 / 188,2016)[8]$ \\
\hline
\end{tabular}

Table 2 Main development metrics and ranks where appropriate for Australia

Western Australia's economy is particularly dependent on mining and petroleum (30\% gross state product 2017-18), which employs three times as many people as agriculture, forestry and fishing. The mining sector has been in decline due to the slowdown of Asian economies, leading to reduced demand for ore and falling ore prices. Six years of declining growth ended in a contraction of $1.8 \%$ in $2016-17$, though the state's economy is recovering, having grown $1.9 \%$ in 2017-18, but this was still below the annual growth rate of $3.8 \%$ over the previous ten years. The state still remains relatively wealthy, gross state product per capita being $\$ 100,367$ in 2017-18, 35\% above Australia's Gross Domestic Product per capita [9]. Economic diversification and the avoidance of economic development being restricted is still seen as a particularly important strategic priority in this state. 


\section{Objectives}

The specific objectives of each marine park differ slightly as they were established under different policy frameworks at different times (NMP 2004: Table 3, SBMP 1995: Table 4).

\begin{tabular}{|l|l|}
\hline Conservation & Operational \\
\hline $\begin{array}{l}\text { Maintain the marine } \\
\text { biodiversity of NMP - } \\
\text { particularly coral reefs, related } \\
\text { fish populations, whale sharks } \\
\text { and manta rays }\end{array}$ & $\begin{array}{l}\text { Promote education, nature appreciation (through recreation and } \\
\text { tourism opportunities) and scientific research in NMP }\end{array}$ \\
\hline $\begin{array}{l}\text { Maintain ecological processes } \\
\text { and life support systems (i.e. } \\
\text { key ecosystem structure and } \\
\text { function) }\end{array}$ & $\begin{array}{l}\text { Facilitate, manage, and where appropriate, assist in the } \\
\text { management of recreational activities in NMP within an } \\
\text { equitable and ecologically sustainable framework }\end{array}$ \\
\cline { 2 - 2 } & $\begin{array}{l}\text { Facilitate manage, and where appropriate, assist in the } \\
\text { management of commercial activities in NMP within an } \\
\text { equitable and ecologically sustainable framework }\end{array}$ \\
\hline
\end{tabular}

Table 3 Objectives for Ningaloo Marine Park [10]

\begin{tabular}{|c|c|}
\hline Conservation & Operational \\
\hline \multirow{5}{*}{$\begin{array}{l}\text { Conserve ecological, cultural } \\
\text { and scenic values - } \\
\text { particularly those related to } \\
\text { seagrass beds, Shark Bay } \\
\text { hosting the world's largest } \\
\text { known seagrass meadow } \\
\text { complex }\left(>4,000 \mathrm{~km}^{2} \text { ) and }\right. \\
\text { associated species, such as } \\
\text { tiger sharks, bottlenose } \\
\text { dolphins, dugong and green } \\
\text { turtles }\end{array}$} & $\begin{array}{l}\text { Facilitate recreation and tourism in a manner compatible with } \\
\text { conservation and other goals. }\end{array}$ \\
\hline & $\begin{array}{l}\text { Involve the community in management of SBMP and promote } \\
\text { appreciation of their values and management through education } \\
\text { and information }\end{array}$ \\
\hline & $\begin{array}{l}\text { Maintain commercial fishing on an ecologically sustainable basis } \\
\text { in the marine park and ensure that other commercial uses are } \\
\text { managed in a manner that minimises impacts on the marine } \\
\text { park's values }\end{array}$ \\
\hline & $\begin{array}{l}\text { Seek a better understanding of the natural and cultural } \\
\text { environments, and the effects of users and management } \\
\text { activities }\end{array}$ \\
\hline & $\begin{array}{l}\text { Promote cooperation, and minimise conflicts, in matters } \\
\text { associated with the use of nearby lands and waters }\end{array}$ \\
\hline
\end{tabular}

Table 4 Objectives for Shark Bay Marine Park [11]

Whilst some of the specific of objectives differ, they revolve around the same broad themes of conserving biodiversity and related values and, from an operational perspective, providing for sustainable compatible uses, promoting research to gain knowledge to inform decisions, promoting education and awarenessraising, and involving the community in decisions.

\section{Drivers/conflicts}

\subsection{Recreational fishing}

The popularity of both marine parks with incoming recreational fishers and their growing numbers is the main driver of conflicts, the main impacts being the depletion of stocks. Recreational fishing is an important source of economic income, livelihoods and relaxation/sport for many local people in Exmouth (Ningaloo) and Denham (Shark Bay). Most fishers travel into these towns from Perth and other population centres, many being engaged in mining and construction industries. They often fish from their own vessels, trailered 
in, though some do use local charter vessels or fish from the shore. Most recreational fishers spend considerable amounts of money on accommodation, meals, fuel, etc., providing important inputs to the local economy. Whilst recreational fishing in Western Australia is amongst the most highly regulated in the world, with many detailed regulations including the requirement for licences [12], the recreational fishing sector still places significant pressures on some stocks, illustrating how recreational fishing can have the potential to pressurise and even collapse stocks within an MPA, given sufficient effort. There are no significant commercial fishing impacts as this is banned throughout NMP and most of SBMP. There are two particularly important recreational fisheries that this analysis focuses on: spangled emperor in NMP and pink snapper in SBMP.

\subsubsection{Spangled emperor fishery in Ningaloo Marine Park}

Spangled emperor (Lethrinus nebulosus) is a very highly prized recreational fishing species, with an estimated boat-based recreational catch of 29 tonnes (2015-16, shore-based catch figures not available), compared to a relatively small commercial catch of 2.6 tonnes (1\% of total regional commercial catch 201516, well within 2-15 tonne commercial catch tolerance range) in the Gascoyne Demersal Scalefish Managed Fishery. The spangled emperor recreational fishery is subject to a number of state-wide restrictions, including a minimum landing size of $41 \mathrm{~cm}$, a daily bag limit of three fish and the general demersal fishing requirement to carry a release weight to sink returned fish as quickly as possible to reduce barotrauma and increase 'catch and release' survival. There is no closed season for spangled emperor in the Gascoyne region but it is provided extra protection in NMP through 18 sanctuary zones (Figure $1(a)$ ) that constitute $33.4 \%$ of the total park area (up from 10\% in 2005), in which all fishing is banned, this being the highest proportion of sanctuary zones of any inshore state-managed MPA in Australia.

The effectiveness of these sanctuary zones, however, is limited by three key factors: (a) displacement of effort into non-sanctuary zones in and beyond NMP; (b) sanctuary zones not matching spangled emperor ranges, one study finding that more than half of tagged fish move at scales greater than the average sanctuary size within NMP [13]; (c) non-compliance leading to poaching in sanctuary zones, an aerial and shore survey finding that $8-12 \%$ boat fishers and $2-4 \%$ of shore-based fishers were observed fishing in sanctuary zones [14]. The final factor is a reflection of the challenges of enforcing sanctuary zones across such a large remote area (NMP is $300 \mathrm{~km}$ long with an area of 2,633 $\mathrm{km}^{2}$ ) and of the arguable lack of surveillance and deterrence capacity (see 7. Incentives). Whilst the Parks and Wildlife Service (PaWS) and Fisheries Division officers go to great lengths to discretely travel to areas to try and detect and catch recreational fishers poaching in sanctuary zones (as well as mounting road checks on fillet possession limits, etc.), there are indications that when they are observed in their patrol vessel en route to a sanctuary zone, some people use short-wave radios or phones to pre-warn other recreational fishers, giving them the opportunity to move out of the sanctuary zones and/or dispose of other evidence of breached restrictions before the patrol arrives. Such factors exacerbate the enforcement challenges as they undermine the potential to catch and deter poachers across 18 sanctuary zones, the likelihood of a given poacher being detected in a given sanctuary zone arguably being relatively low. Enforcement is further challenged by the tendency for the Fisheries Division to mainly apply fixed penalty infringements where education and warnings have failed (7. Incentives), noting that it is the Fisheries Division that pursue such deterrents even if a PaWS officer catches the offender. This tends to lead to a relatively low fine, providing insufficient deterrence in the unlikely event that poaching is detected. Despite these challenging factors, a recent analysis of data from 1987-2017 indicates that L. nebulosus are $42 \%$ more abundant and have $86 \%$ more biomass inside NMP's sanctuary zones than outside, though the magnitude of this positive reserve effect was not as great compared to studies of lethrinids in other parts of the world [15], probably mainly due to factors b) and c) noted above, coupled with habitat effects, natural variability and variable approaches to monitoring. 
There is, however, evidence that "spangled emperor have notably declined since 1991 across NMP, with this decline somewhat buffered inside sanctuary zones relative to outside" [16, p.12]. One startling illustration of this wider decline is that spangled emperor in one of the original (pre-2005) sanctuary zones (Osprey) had reduced by $50 \%$ in the 9 year period between 1987 and 2006, with nearby fished areas showing a $90 \%$ reduction $[16$, p.92]. This indicates that spangled emperor populations in some areas of NMP were severely overfished and that whilst the resulting declines may have been less severe in sanctuary zones, overall the population was in a much depleted state. It is also noted that "sanctuary zones alone may not be adequate to the recovery of these populations or even stopping their decline", particularly given the under-

representation of reef slope and deep water reef flat even after the sanctuary expansion in 2005 [16, p.25]. More recent assessments have been inconclusive, indicating that the spangled emperor population in NMP area has remained stable in the last decade, and it remains to be seen whether the sanctuary zone expansion coupled with wider restrictions will provide for the recovery of spangled emperor in NMP from their historical 1991-2006 declines (General Sources for section 4.1.1 - [17, 18], correspondence with Fisheries Division Officers including unreleased data, interview findings).

\subsubsection{Pink snapper fishery in Shark Bay Marine Park}

Pink snapper (Pagrus auratus) is highly prized by recreational fishers due to the fight it takes to land and its high culinary qualities. It is also an important commercial fishery at a wider regional scale, representing $56 \%$ (150 tonnes, 2015-16) of total finfish catch by weight in the Gascoyne Demersal Scalefish Managed Fishery, for which it is an indicator species, considered at moderate risk. It is a long-lived, slow-growing and latematuring demersal fish, so is particularly susceptible to over-exploitation, the wider stock for the Gascoyne region being at just $20 \%$ of unfished biomass in 2015/16, considered 'inadequate'. Pink snapper in Shark Bay are adapted to three different hypersalinity zones, with three genetically separate stocks in the gulfs to the east and west of Peron Peninsula and in the Freycinet Estuary (Figure 1(b)), along with an oceanic stock in deeper areas outside Shark Bay. Only the oceanic stock is open to commercial fishing and this is considered to be recovering from historical overfishing, with the 2015 stock at between $32-38 \%$ of the unfished biomass, predicted to reach the target level of $40 \%$ by 2021 . Concerns were raised in the 1990 's about the three inner Shark Bay stocks as the recreational fishing catch was estimated to have risen from 40 tonnes in 1983 to more than 100 tonnes in 1995.

Assessments in 1997/98 indicated the collapse of the pink snapper stock to less than $10 \%$ of unfished biomass in the gulf to the east of Peron Peninsula, the other two stocks also showing severe depletions, due to excessive catches by the recreational (mainly) and commercial sectors (bycatch), leading to the complete closure of the Shark Bay pink snapper fishery from 1998-2003. When assessments in 2003 indicated that the stocks had recovered to their target level of $40 \%$ of unfished biomass (except in Freycinet Estuary), the fishery was re-opened, subject to an innovative integrated fisheries management approach, whereby a combined annual total TAC was set for both commercial and recreational fishing. A commercial bycatch TAC of 2 tonnes was allocated for beach seine netting in General Use or Special Purpose Areas around Denham (west of Peron Peninsula) for which there are only six active licences, with only 1 tonne of such bycatch in 2015. There are also very restricted periods of prawn and scallop dredging allowed for a few days in small zones in outer areas of SBMP, with strict conditions, including no significant pink snapper bycatch, though some locals do object to this dredging in SBMP. A recreational TAC of 35 tonnes was also set, divided amongst the separate stocks in the inner gulfs to the east ( 15 tonnes) and west ( 15 tonnes) of Peron Peninsula, with a TAC of 5 tonnes for the Freycinet Estuary, where stocks had only recovered to $30 \%$ of their unfished biomass in 2003. There are also many other restrictions, e.g. closed seasons (1 May - 31 July in gulf to east of Peron Peninsula; 15 August - 30 September in Freycinet Estuary; open each year until TAC reached in gulf to west of Peron Peninsula); minimum landing size $50 \mathrm{~cm}$ (previous maximum landing size $70 \mathrm{~cm}$ removed in 2016); daily bag limit of two fin fish per fisher (increased from one in 2013); total possession (including on exiting the area by road, boat, etc.) limit of $5 \mathrm{~kg}$ of pink snapper in Freycinet Estuary management zone and $20 \mathrm{~kg}$ of fin fish fillets (all species) outside this zone (state-wide, both limits aimed to 
end 'fill your freezer' days); ban on export of fillets by 'unaccompanied consignment'; and requirement to carry a release weight to sink returned fish as quickly as possible to reduce barotrauma and increase 'catch and release' survival. In addition, a novel tag lottery system was implemented in 2003 to carefully manage the uptake of the Freycinet Estuary TAC, whereby this TAC ( 5 tonnes) was divided to allocate a limited number of tags (1200 in 2003 increased to 1400 in 2006), made available for purchase each year through a lottery. Those fishers hoping to land and retain a pink snapper could enter the lottery and each fisher was limited to winning two tags. Only those fishers who had won and were in possession of a tag could retain a caught pink snapper, the requirement being to insert the tag into the whole fish's mouth on landing and secure it with a tamper proof lock. The tag lottery system was replaced in 2016 with the wider bag and fillet limit.

The most recent stock assessments up to 2012-13 indicate that the Eastern Gulf stock was at $80 \%$ of its unfished level (indicating within current recreational fishing TAC of 12 tonnes), the Denham Sound stock (west of Peron Peninsula) was at $75 \%$ of its unfished level (indicating within current recreational fishing TAC of 12 tonnes) and the Freycinet Estuary stock was at between $42-57 \%$ of its unfished level (indicating within current recreational fishing TAC of 3.8 tonnes), all indicating that these stocks have recovered and are no longer subject to recruitment overfishing. The recovery of Shark Bay's pink snapper stocks is considered to represent an effective combination of scientific assessments, community support and novel governance approaches, being an innovative example of management that has provided for stock recovery from overfishing by the recreational sector (General Sources for section 4.1.2 - [17, 18, 19, 20, 21], correspondence with Fisheries Division Officers including unreleased data, interview findings).

\subsection{Marine wildlife tourism}

Both marine parks are also very popular for marine wildlife tourism. This includes whale shark watching through snorkelling from vessels in Ningaloo, and bottlenose dolphin watching from Monkey Mia beach in Shark Bay, along with other activities such as diving/snorkelling on coral reefs (Ningaloo) and seagrass (Shark Bay), general marine wildlife observation cruises, and observing ancient Stromatolites in Hamelin Bay Marine Reserve (alongside Shark Bay Marine Park and part of the World Heritage Site). This section will focus on the potential impacts of marine wildlife tourism on two iconic species: whale sharks and Indo-Pacific bottlenose dolphins.

\subsubsection{Whale shark watching in Ningaloo}

Ningaloo is famous for the 'ecotourism' opportunities to swim (with mask and snorkel) with whale sharks (Rhincodon typus), as they aggregate in this area every year between March and August, probably due to a combination of bathymetric features (shallowness, proximity to deep water, steep slope) that make this area very productive as a feeding ground for these zooplanktivorous surface filter feeders [22]. The whale shark is the largest non-cetacean animal in the world, growing up to $\sim 12$ metres in length ( 21 tonnes), and is recognised as 'endangered' due to the impacts of fishing, both as bycatch and as a target, of collisions by ships and smaller vessels, of oil and gas operations and of recreational/tourism activities, coupled with its long life span and late maturation. Whilst detailed population assessment data is lacking, it is widely recognised that the global population is 'decreasing' [23]. Being a wide ranging species, many threats to whale sharks are faced when they migrate beyond the NMP area. Tagging studies indicate that they can travel up to $1000 \mathrm{~km}$ to seas near Indonesia, Timor and Christmas Island. Evidence has been reported that the whale shark population that visits NMP ( 130 mainly juvenile males, $65 \%$ being return visitors) is declining in size and age [16, p.73], and that they may be showing signs of disturbance (neutral behaviours and directional changes) when tourism vessels are present [24].

As one of the 'outstanding universal values' that the Ningaloo Coast World Heritage Site was listed to protect, the regulation of the whale shark ecotourism sector in Ningaloo is a high priority. This sector began to significantly develop in 1993, the total number of passengers interacting with whale sharks having grown 
from $\sim 11,000$ in 2007 to 27,000 in 2016 (increase of 32\% on 2015). This makes a very important contribution to the local economy, swimming with whale sharks being the main attraction for many national and international tourists that visit Exmouth. Only 15 licences are issued for whale shark watching vessels, with many strict conditions attached through a statutory code of conduct, relating, for example, to the number (10 maximum) and behaviour of swimmers in the water, the positioning, speed and track of vessels relative to the whale sharks, real time reporting to PaWS, through a 'black box' electronic monitoring system (EMS), of the activities of each vessel, and the collection of a user fee (AUS\$18 adults) as part of the cost of a day tour by the operators. Spotter planes, collectively funded by operators, help guide the vessels towards the track of given whale shark, only one vessel being allowed to deploy swimmers at a time, the waiting vessels having to stand $>400$ metres back.

The details of this governance framework are discussed later, noting that the management of whale shark watching in Ningaloo is widely recognised as world-leading good practice of ecologically sustainable whale shark ecotourism [25], with no evidence that repeated encounters with swimming tourists were significantly affecting whale shark behaviour and visitation patterns, variability in environmental parameters having a far greater influence [26], despite reported signs of disturbance when tourism vessels are present [24]. Building on this, the extension of this sector to swimming with humpback whales (Megaptera novaeangliae) was successfully trialled in 2016, involving 1,644 people, subject to similarly detailed regulatory and monitoring requirements (General sources for section 4.2.1 - [16, pp.72-76, 27], interview findings)

\subsubsection{Dolphin watching at Monkey Mia}

Shark Bay contains a resident population of $\sim 3000$ Indo-Pacific bottlenose dolphins (Tursiops cf. aduncus), $\sim 600$ of which reside in the vicinity of Monkey Mia (Figure 1b). Fishermen have been feeding fish to dolphins from the pier and beach at Monkey Mia since the 1960s, this being the longest running known wild bottlenose dolphin feeding site in the world. It soon began to attract a growing number of visitors to watch and feed the dolphins, managed on a voluntary basis by the private sector, including the owners of tourism enterprises that grew in response to growing numbers of visitors. However, research begun in 1984 found that nursing mothers were neglecting their calves, leading to a much higher mortality rate (11 of 12 calves died from 1987-94) compared to calves of non-provisioned mothers, so in 1989 the local 'Shire' government and the Department of Conservation and Land Management (CALM, now PaWS) began to regulate the feeding activities and in 1994 CALM took over the management of these activities. Banning dolphin provisioning was decided against, as the local economy had become significantly dependent on the growing number of visitors, $98 \%$ of whom visit Monkey Mia mainly to observe and hopefully feed the dolphins. Instead, CALM introduced stricter restrictions and regulations to reduce these impacts, the associated officer costs being contributed to by a Monkey Mia entrance fee (AUS\$12 adults). These specific regulations apply in the small recreation zone that extends to an 80 metre radius from the end of the Monkey Mia jetty (Figure 1(b)), within and from which a single strictly regulated marine wildlife tour catamaran also operates. Another catamaran operates in Shark Bay but is not licenced to operate in Monkey Mia recreation zone, rivalry between the two operators being intense. Only five specific mature females selected from three matrilines are allowed to be offered fish and feeding ends when each has visited three times to receive up to four fish (total $<2 \mathrm{~kg}$ equivalent to $10 \%$ of daily dietary requirements), or at midday, whichever comes sooner. Tourists are carefully briefed and supervised, with only a few randomly selected to offer fish and all being required to remain at the edge of the beach in very shallow water, and not touch the dolphins.

Some concerns remain at the ethics of provisioning these 'wild animals' in order to attract tourists, alongside concerns based on the eco-spiritual veneration that some have for these dolphins. However, these restrictions have successfully reduced calf mortality from $86.9 \%$ (1991-1994) to 13.3\% (1995-2010), which is not statistically different to the survival rate for calves of non-provisioned mothers. Whilst there are still reductions in maternal care by provisioned mothers that lead to some changes in calf behaviour, particularly increased foraging whilst their mothers were being provisioned, these do not seem to affect calf 
development or survival [28, 29]. Around 100,000 tourists visit Monkey Mia each year, their spending representing $\sim 30 \%$ of the local Shark Bay economy. Whilst there are some people that still argue for stricter regulation or even the banning of provisioning to better protect dolphins, and some people (including tourists) who argue for less regulations to promote better tourist experiences and more tourist visits and income, the balanced management of dolphin provisioning at Monkey Mia is recognised as world-leading good ecotourism practice (General sources for section 4.2.2 - [30, pp.82-101, 31], interview findings).

\subsection{Oil industry}

There are also concerns related to two floating production, storage and offloading vessels extracting oil approximately $20 \mathrm{~km}$ north of NMP, the regulation of which by the state's Environmental Protection Agency must mitigate any risks to NMP, particularly from potential oil spills. Recent related proposals [32] to construct and operate the Learmonth onshore pipeline fabrication facility $35 \mathrm{~km}$ south of Exmouth are becoming controversial, even though there will be no direct impacts on NMP, as the 'bundles' of pipelines will be transported $10 \mathrm{~km}$ along two dedicated rail tracks to Heron Point, to be launched into Exmouth Gulf and towed by barges to the oil extraction facilities to the north. Whilst only three launches (each lasting two days) per year are proposed and neither the fabrication nor the Heron Point launch facility are in NMP (or the related WHS), some environmentalists fear that this represents the beginnings of the industrialisation of the area to service the nearby oil fields [33, 34].

\subsection{Sheep grazing}

Sheep stations on riparian land around Shark Bay are also leading to concerns about the impacts of exacerbated sediment discharges from run-off during typhoon rain events because of (a) over-grazing, which increases the exposure of soil surface to rain and undermines the sediment binding capacity of vegetation root systems, and (b) poor drainage ditch management, which can lead to enhanced sediment run-off. The 2010-2011 'Ningaloo Niña' discussed below led to seagrass smothering by sediment discharges from run-off during intense cyclone rain events in Shark Bay, resulting in catastrophic $(>90 \%)$ seagrass die-back in several regions, this being a particular concern given the importance of seagrass as a foundation species [35]. Whilst some sediment run-off during typhoon rain events is inevitable, this can be exacerbated where land has been more intensely grazed and where ditches have not been managed to minimise water and sediment run-off.

\subsection{Climate change}

Whilst this is not a driving force that can be addressed at a marine park governance level, it is important to recognise that both marine parks are also under increasing pressure from climate change, with concerns about the potential for coral bleaching and seagrass die-backs. There have been significant bleaching events in both parks, e.g. the reefs on the fringes of SBMP showed $30-100 \%$ bleaching (visual estimates) and the Exmouth Gulf of NMP showed average bleaching of $95 \%$ and consequent coral reef cover losses of $84 \%$ (quantitative assessments) as a result of extreme La-Niña conditions that caused extensive warming currents from October 2010 to May 2011 [36].

Climate change also impacts seagrass through sediment smothering, when intense rain associated with a cyclone washes sediment into the bay, which may be exacerbated by land management on sheep stations (as discussed above), overall seagrass area losses due to sediment smothering in Shark Bay following Ningaloo Niña having been estimated at 22\% (compared with 2002), representing the loss of $900 \mathrm{~km}^{2}$ of seagrass meadow. These losses also led to declines in the density of populations of several specialist seagrass species, particularly sea snakes (76.7\% decline), dugongs (67.5\%), bottlenose dolphins (39.2\%), green turtles (38.6\%) and pied cormorants (35.3\%) [37], the incidence and potential trophic effects of these declines underlining the importance of seagrass as a foundation species [35]. The seagrass losses are also estimated to have led to the release of between 2 and 9 million tonnes of carbon dioxide (or equivalent) in 
the following three years. If these losses were included in Australia's national greenhouse gas emissions figures, they would have increased emissions figures for land use change by between 4 and 21\% [38]. There are related concerns that continued warming is undermining the recovery of the Shark Bay ecosystem, particularly with regard to the replacement of the more productive and structurally complex temperate seagrass Amphibolis antarctica with the less productive and structurally complex tropical seagrass Halodule uninervis, as sea temperatures rise [39]. The increased likelihood of future marine heatwave events and related cyclones, coupled with ongoing gradual warming pushing the temperate seagrass beyond its thermal survival range, have led to the SBMP and related WHS being classified as having a high vulnerability to climate change, following a September 2018 workshop convened by the Shark Bay World Heritage Advisory Committee [40] employing the Climate-change Vulnerability Index (CVI), which was developed to systematically assess climate change impacts across all World Heritage properties [41].

\section{Governance approach}

Both marine parks are categorised as government-led, in that they were instigated and are governed primarily by the state under a clear legal framework. At a Government of Western Australia state level, the Parks \& Wildlife Service (PaWS, now part of the Department of Biodiversity, Conservation and Attractions) is primarily responsible for marine parks, in partnership with the Fisheries Division (now part of the Department of Primary Industries and Regional Development), along with other relevant state and federal authorities (Figure 2), mainly under the Conservation and Land Management (CALM) Act (1984). The Conservation and Parks Commission has the vested responsibility for all lands and waters designated under the CALM Act, and it advises the state government on the development of policies to conserve and sustainably use designated areas, including the preparation of management plans for marine parks and evaluation of the effectiveness of their implementation by relevant departments.

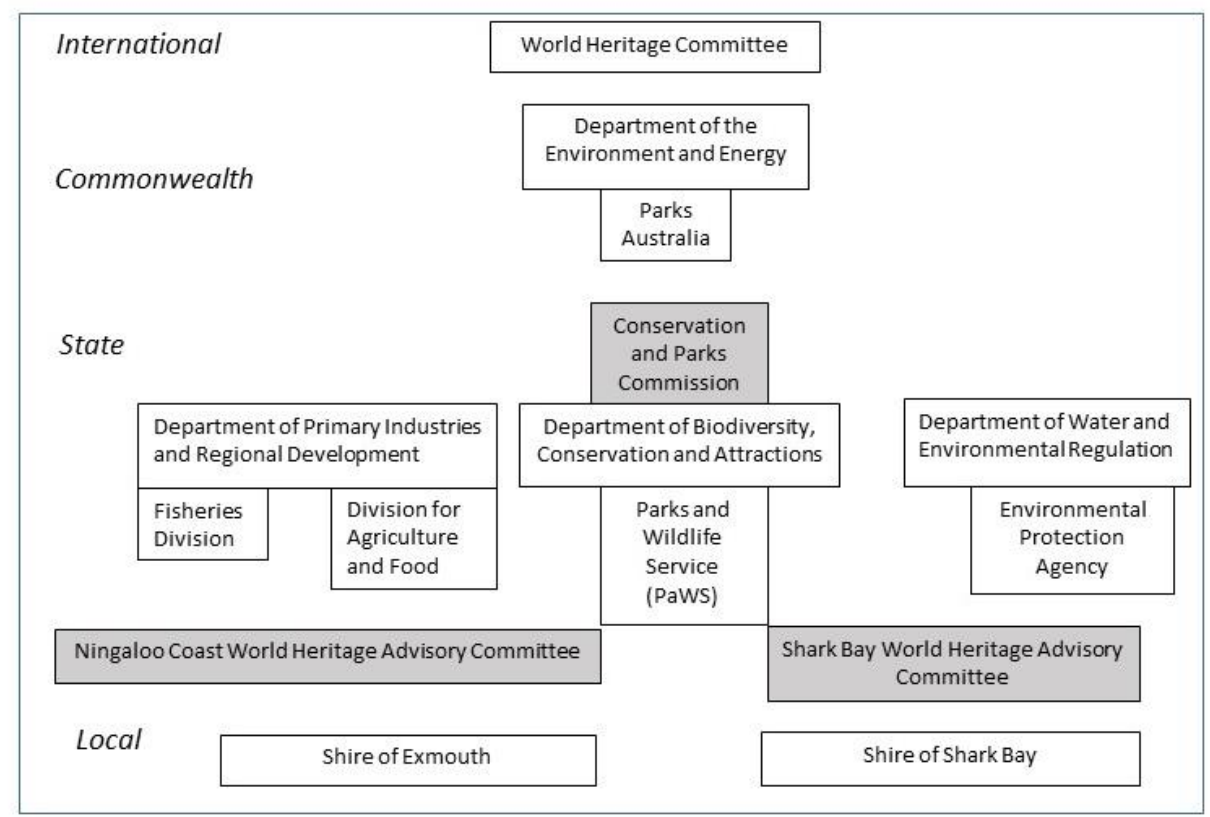

Figure 2 Organigram of main state organisations involved in marine park governance in Western Australia (shaded organisations have a mainly advisory role)

Specific legislative orders are made for the regulation of activities in the marine parks under the CALM Act, particularly for recreational activities related to the protection of specific habitats and species, and under the Fish Resources Management Act (1994), particularly for recreational and commercial fishing. Both marine parks have a zonation scheme (Figure 1), which is also implemented through such specific legislative 
orders, no-take sanctuary zones constituting $18 \%$ of SBMP area and $33.4 \%$ of NMP area. NMP is the main part of the Ningaloo Coast World Heritage Site (designated 2011), whilst SBMP is the main inshore part of the Shark Bay World Heritage Site (designated 1991). Both are managed by the federal government under the Environment Protection and Biodiversity Conservation (EPBC) Act (1999), indirectly subject to international obligations to conserve the 'outstanding universal values' for which these natural WHSs were listed under the UNESCO World Heritage Convention (1972).

NMP has the adjoining Muiron Islands Marine Management Area $\left(286 \mathrm{~km}^{2}\right)$ to the north (Figure 1(a)), which is mostly zoned for multiple-uses, with some small conservation areas where special rules apply to recreational fishing. SBMP has the adjoining and more strictly protected Hamelin Bay Marine Reserve $(1,270$ $\mathrm{km}^{2}$ of SBWHS) in the most saline inshore section (Figure 1(b)), designated largely to protect the world's most diverse and abundant living examples of primordial stromatolites. Both adjoining state MPAs are also part of the respective WHSs (Figure 1).

Both state marine parks also have adjoining commonwealth marine parks extending offshore as state jurisdiction only extends out to 3 nautical miles from the baseline. NMP has the adjoining Ningaloo Marine Park (Commonwealth Waters), consisting of recreational use zones (95\% area) and a national park zone (5\% area) totalling $2,435 \mathrm{~km}^{2}$, which covers the offshore $\sim 48 \%$ of the WHS marine area. SBMP and the wider Shark Bay WHS ( 70\% of which is marine) are confined to state waters, SBMP and inshore Hamelin Pool Marine Nature Reserve designations covering only the relatively used inshore $60 \%$ of the total WHS marine area, the outer $40 \%$ 'grey zone' not being subject to a specific protective designation. There is the adjoining offshore commonwealth Shark Bay Marine Park (multiple use zone 7,443 $\mathrm{km}^{2}$ ) extending beyond the WHS and state waters. Both seaward adjoining designations are under commonwealth jurisdiction under the EPBC Act and these designations and management plans are currently being reviewed, along with most of the more recently designated Commonwealth marine parks. This analysis will focus on the state marine park designations in the context of the wider WHSs.

Each of the WHSs related to these marine parks has an official World Heritage Advisory Committee [40, 42] consisting of representatives of various sectors, each of whom is appointed through a formal state and commonwealth process. These committees provide advice to the Minister for the Environment (Department of Biodiversity Conservation and Attractions) at a state level and the Environment Protection Heritage Council (Department of the Environment and Energy) at a Commonwealth level (Figure 2). They meet every few months to discuss specific issues, particularly related to the priority of preserving the 'outstanding universal values' that each of the WHSs, of which the marine parks are a part, was designated to protect. All decisions related to the management of activities within the parks are also subject to official public consultation processes.

On an operational basis, PaWS and Fisheries Division officers are responsible for surveillance of activities within these marine parks, including joint patrols, with prosecutions for fisheries offences being pursued by Fisheries Division officers and other prosecutions related to marine species and habitat disturbance being pursued by PaWS officers.

\section{Effectiveness}

Both marine parks have been assigned an effectiveness score of 3: some impacts completely addressed, some are partly addressed. The impacts of recreational activities other than fishing, such as whale shark and dolphin watching, are largely considered to have been effectively mitigated, but the status of some recreationally fished stocks remains a concern, particularly given past stock depletions and the trend towards increasing effort at both sites (see section 4.1). Given the recent trend towards increasing numbers of recreational fishers and of the effort each can exert (as a result of technological creep), coupled with measures to protect and restore stocks, the trend in effectiveness is considered stable. Despite concerns 
about the overfishing of some populations in the parks, there is no evidence of trophic cascade effects of such depletions, evidence for NMP indicating that these coral reef ecosystems are relatively stable, showing high degrees of species diversity and abundance $[16$, p.25].

Furthermore, recent estimates of maximum vertical reef accretion potentials for coral reefs around the world show that NMP's reefs have amongst the high carbonate budgets and reef accretion potentials in the Indian Ocean [43], indicating that local pressures from tourism, recreational fishing, pollution, etc., along with the wider-scale impacts of bleaching events, are not undermining the ecological capacity of most of NMP's reefs to accrete at a sufficient rate to just about keep up with current rates of sea level rise.

However, it is also projected that under any other than the most optimistic climate change mitigation scenarios, accretion on Ningaloo's reefs, like most reefs around the world, will not be able to keep up with sea level rise and by 2100 will exceed the threshold depth increase level $(50 \mathrm{~cm})$, when erosive wave energy is likely to further reduce coral reef cover, further undermining the capacity of the reefs to accrete [43]. Given that coral reef accretion is likely to be further reduced as bleaching events are predicted to increase in frequency and severity as a result of climate change [43], the triple synergistic impacts of climate change: increased depth, increased wave energy and increased bleaching (quadruple if impacts of ocean acidification on coral reefs [44] are also factored in) present a pessimistic scenario for NMP's (and SBMP's) reefs, given the bleaching events discussed above. This is despite the fact that the effectiveness of present protection means NMP's reefs show high degrees of coral cover and wider species diversity and abundance, i.e. resilience, thereby having amongst the highest vertical reef accretion potentials in the world.

There are also concerns (discussed above in section 4. Drivers/conflicts) for SBMP related to recent die-backs of seagrass (2010-11) due to intense cyclone rainfall events, which may be globally exacerbated by climate change and locally exacerbated by increased sediment run-off as a result of riparian land use and management. The reduction of grazing and improved ditch management on riparian land around Shark Bay has the potential to reduce the pulse of sediment-laden floodwater that can result from cyclone rain events and thereby reduce the impacts on seagrass of smothering. Coupled with other restrictions on activities that can impact seagrass beds, such measures can help promote the resilience of this crucial habitat, but ongoing climate change is likely to lead to ongoing losses of seagrass area and potentially detrimental changes in seagrass species composition.

The habitats in both marine parks are sensitive to climate change, including through ocean warming events leading to bleaching, concerns about which have been heightened by recent severe bleaching events in Australia's most iconic marine WHS, the Great Barrier Reef Marine Park [2, 3]. As noted above, the coral reefs in both NMP and SBMP suffered major bleaching as a result of 'Ningaloo Niña' in 2010-11 [36]. As there is clearly nothing that can be done at an MPA governance level to mitigate climate change, it is important to focus on the details of the governance framework that is in place to address proximal impacts related to the conflicts noted above, in order to promote the resilience of the MPAs' ecosystems to climate change.

\section{Incentives}

The incentives applied and those that are particularly important priorities for strengthening or introducing to better mitigate conflicts and improve effectiveness are summarised below for Ningaloo Marine Park (Table 5) and Shark Bay Marine Park (Table 6). Full details of these incentives for each case study can be found in Supplementary Table 1 (NMP) and 2 (SBMP). The numbers before each incentive are based on the numbered taxonomy of 36 incentives [5].

\begin{tabular}{|l|l|l|}
\hline Incentive (I) & Used & How/why? \\
\hline Economic & $\mathrm{Y}^{*}$ & $\begin{array}{l}\text { Detailed regulations to exclude commercial fishing from NMP } \\
\text { and manage recreational fishing, but concerns remain about }\end{array}$ \\
\hline
\end{tabular}




\begin{tabular}{|c|c|c|}
\hline $\begin{array}{l}\text { 4. Promoting } \\
\text { profitable and } \\
\text { sustainable fishing and } \\
\text { tourism }\end{array}$ & & $\begin{array}{l}\text { effectiveness of sanctuary zones and the potential for } \\
\text { overexploitation of some stocks, particularly spangled emperor. } \\
\text { Detailed regulations to manage other tourism activities, } \\
\text { particularly snorkelling with whale sharks (world leading example } \\
\text { of good practice) and manta rays, but concerns remain about } \\
\text { impacts of casual encounters. }\end{array}$ \\
\hline $\begin{array}{l}\text { 5. Promoting green } \\
\text { marketing }\end{array}$ & $Y$ & $\begin{array}{l}\text { NMP marketed as premium ecotourism destination, including } \\
\text { through its recognition as a WHS that is effectively protected. }\end{array}$ \\
\hline $\begin{array}{l}\text { 6. Promoting } \\
\text { diversified and } \\
\text { supplementary } \\
\text { livelihoods }\end{array}$ & $Y$ & $\begin{array}{l}\text { Marine wildlife tourism provides an important alternative to } \\
\text { reliance on commercial and recreational fishing. Permanent and } \\
\text { seasonal officer posts also create opportunities. }\end{array}$ \\
\hline $\begin{array}{l}\text { 9. Provision of state } \\
\text { funding }\end{array}$ & $\mathrm{Y}^{*}$ & $\begin{array}{l}\text { Fisheries Division and PaWS are reasonably well funded but this } \\
\text { could be less short-term to enable strategic approach. }\end{array}$ \\
\hline $\begin{array}{l}\text { 10. Provision of NGO, } \\
\text { private sector and } \\
\text { user fee funding }\end{array}$ & $Y$ & $\begin{array}{l}\text { Whale shark watching fees and fishing licence fees support } \\
\text { monitoring and research. Industry and NGO funding also } \\
\text { supports research. }\end{array}$ \\
\hline$\frac{\text { Communication }}{11 . \text { Raising awareness }}$ & $Y$ & $\begin{array}{l}\text { Extensive use of leaflets, signs, web sites, officers, briefings, } \\
\text { PaWS interpretation facilities, etc. to raise awareness of the } \\
\text { ecological values of NMP, including Ningaloo Centre in Exmouth } \\
\text { with aquaria, etc. }\end{array}$ \\
\hline $\begin{array}{l}\text { 12. Promoting } \\
\text { recognition of benefits }\end{array}$ & $Y$ & $\begin{array}{l}\text { Focus in awareness raising of importance of restrictions to } \\
\text { promote sustainability. }\end{array}$ \\
\hline $\begin{array}{l}\text { 13. Promoting } \\
\text { recognition of } \\
\text { regulations and } \\
\text { restrictions }\end{array}$ & $Y$ & $\begin{array}{l}\text { Extensive use of leaflets, signage, web sites, officer briefings, etc. } \\
\text { to promote recognition of regulations and restrictions, including } \\
\text { a smartphone app for recreational fishers. }\end{array}$ \\
\hline $\begin{array}{l}\text { Knowledge } \\
\text { 14. Promoting } \\
\text { collective learning }\end{array}$ & $\mathrm{Y}^{*}$ & $\begin{array}{l}\text { Collaborations between scientists, regulators, recreational } \\
\text { fishers, marine wildlife tourism operators and tourists to gather } \\
\text { data, funded by state and industries. Community-based } \\
\text { programmes would help to draw on local knowledge and build } \\
\text { trust [45]. }\end{array}$ \\
\hline $\begin{array}{l}\text { 15. Agreeing } \\
\text { approaches for } \\
\text { addressing uncertainty }\end{array}$ & $Y$ & $\begin{array}{l}\text { Precautionary approach provided for in whale shark watching } \\
\text { policy [27]. Expansion of sanctuary zones in } 2005 \text { to relative high } \\
\text { of } 33.4 \% \text { could be considered a precautionary approach. }\end{array}$ \\
\hline $\begin{array}{l}\text { 16. Independent } \\
\text { advice and arbitration }\end{array}$ & $Y$ & $\begin{array}{l}\text { Commonwealth and industry funded research provides advisory } \\
\text { role and World Heritage Committees provide some arbitration } \\
\text { roles. }\end{array}$ \\
\hline $\begin{array}{l}\text { Legal } \\
\text { 17. Hierarchical } \\
\text { obligations }\end{array}$ & $Y$ & $\begin{array}{l}\text { Obligations under World Heritage Convention, commonwealth } \\
\text { and state legislation. }\end{array}$ \\
\hline $\begin{array}{l}\text { 18. Capacity for } \\
\text { enforcement }\end{array}$ & $\mathrm{Y}^{*}$ & $\begin{array}{l}\text { Officers patrol by vehicle, boat, plane and foot but need for } \\
\text { improved enforcement of sanctuary zones. Electronic monitoring } \\
\text { system mandatory for commercial whale shark watching vessels } \\
\text { [27]. }\end{array}$ \\
\hline $\begin{array}{l}\text { 19. Penalties for } \\
\text { deterrence }\end{array}$ & $\mathrm{Y}^{*}$ & $\begin{array}{l}\text { Large penalties can be imposed but tendency for Fisheries } \\
\text { Division to issue smaller fixed penalty fines, rather than pursuing }\end{array}$ \\
\hline
\end{tabular}




\begin{tabular}{|c|c|c|}
\hline & & $\begin{array}{l}\text { larger penalties through prosecutions in court, undermines } \\
\text { deterrence, where larger penalties through more prosecutions } \\
\text { would provide a stronger deterrent. }\end{array}$ \\
\hline $\begin{array}{l}\text { 21. Attaching } \\
\text { conditions to use and } \\
\text { property rights, } \\
\text { decentralisation, etc }\end{array}$ & Y & $\begin{array}{l}\text { Strict requirements for marine wildlife watching and recreational } \\
\text { fishing charter vessels to comply with licence conditions related } \\
\text { to conservation objectives, including conditions for marine } \\
\text { wildlife watching detailed in the statutory Code of Conduct. }\end{array}$ \\
\hline $\begin{array}{l}\text { 22. Cross-jurisdictional } \\
\text { coordination }\end{array}$ & $\mathrm{Y}^{*}$ & $\begin{array}{l}\text { Legal obligations for other sectoral regulators to exercise their } \\
\text { functions to promote achievement of NMP objectives; } \\
\text { collaboration and cross-authorisation between Fisheries Division } \\
\text { and PaWS officers but coordination could be improved, } \\
\text { particularly regarding penalties for deterrence (I-19) }\end{array}$ \\
\hline $\begin{array}{l}\text { 23. Clear and } \\
\text { consistent legal } \\
\text { definitions }\end{array}$ & $Y$ & $\begin{array}{l}\text { Clear and consistent definitions between commonwealth and } \\
\text { state legislation and related sectoral legislation }\end{array}$ \\
\hline $\begin{array}{l}\text { 25. Legal adjudication } \\
\text { platforms }\end{array}$ & $Y$ & $\begin{array}{l}\text { Cases can be appealed to state and commonwealth courts and } \\
\text { international World Heritage Committee can provide an } \\
\text { adjudication role }\end{array}$ \\
\hline $\begin{array}{l}\text { 26. Transparency, } \\
\text { accountability and } \\
\text { fairness }\end{array}$ & $\mathrm{Y}^{*}$ & $\begin{array}{l}\text { Detailed research and monitoring information needs to be made } \\
\text { more publicly available as lack of access is a hurdle to adaptive } \\
\text { collaborative management. Local people in particular want more } \\
\text { access to scientific information [45] }\end{array}$ \\
\hline $\begin{array}{l}\frac{\text { Participation }}{27 . \text { Rules for }} \\
\text { Participation }\end{array}$ & $Y$ & $\begin{array}{l}\text { Clear rules for user participation on Ningaloo Coast World } \\
\text { Heritage Advisory Committee }\end{array}$ \\
\hline $\begin{array}{l}\text { 28. Establishing } \\
\text { collaborative } \\
\text { platforms }\end{array}$ & $\mathrm{Y}^{*}$ & $\begin{array}{l}\text { I-27 provides for participation of representatives of sectoral user } \\
\text { groups but particular need for recreational fishing sector to be } \\
\text { specifically represented }\end{array}$ \\
\hline $\begin{array}{l}\text { 31. Decentralising } \\
\text { responsibilities }\end{array}$ & $Y$ & $\begin{array}{l}\text { Some commonwealth responsibilities decentralised to state } \\
\text { authorities, particularly for fisheries and parks \& wildlife }\end{array}$ \\
\hline 32. Peer enforcement & $Y$ & $\begin{array}{l}\text { Recreational fishers can encourage peer compliance and report } \\
\text { infringements via an anonymous phone hotline. Marine wildlife } \\
\text { tourism operators provide mutual surveillance role, partly as a } \\
\text { result of competition for licences. }\end{array}$ \\
\hline $\begin{array}{l}\text { 33. Building trust and } \\
\text { the capacity for } \\
\text { cooperation }\end{array}$ & $\mathrm{Y}^{*}$ & $\begin{array}{l}\text { Ningaloo Coast World Heritage Advisory Committee promotes } \\
\text { this, as do contacts and discussions between officers and various } \\
\text { users, but there are some tensions with the recreational fishing } \\
\text { sector. I-14 could help build trust with wider community [45] }\end{array}$ \\
\hline $\begin{array}{l}\text { 34. Building linkages } \\
\text { between relevant } \\
\text { authorities and user } \\
\text { representatives }\end{array}$ & $\mathrm{Y}^{*}$ & $\begin{array}{l}\text { Key user representatives appointed to Ningaloo Coast World } \\
\text { Heritage Advisory Committee but development of links with } \\
\text { specific recreational fishing representatives could help address } \\
\text { tensions }\end{array}$ \\
\hline $\begin{array}{l}\text { 35. Building on local } \\
\text { customs }\end{array}$ & $Y$ & $\begin{array}{l}\text { Indigenous aboriginal Australian practices are provided for and } \\
\text { their knowledge is drawn on, with approaches being developed } \\
\text { for joint management, including the recruitment of several } \\
\text { indigenous trainee rangers. }\end{array}$ \\
\hline
\end{tabular}




\begin{tabular}{|l|l|l|}
\hline $\begin{array}{l}\text { 36. Potential to } \\
\text { influence higher } \\
\text { institutional levels }\end{array}$ & $Y$ & $\begin{array}{l}\text { Ningaloo Coast World Heritage Advisory Committee can } \\
\text { influence state, commonwealth and even international decisions, } \\
\text { latter by UNESCO under World Heritage Convention }\end{array}$ \\
\hline
\end{tabular}

Table 5 Incentives applied in Ningaloo Marine Park Incentives applied $(\mathrm{Y})$, including those that are particularly important priorities for strengthening $\left(\mathrm{Y}^{*}\right)$ and introducing $\left(\mathrm{N}^{*}\right)$ (Detailed version - Supplementary Material, Table 1)

\begin{tabular}{|c|c|c|}
\hline Incentive (I) & Used & How/why? \\
\hline $\begin{array}{l}\text { Economic } \\
\text { 4. Promoting } \\
\text { profitable and } \\
\text { sustainable fishing and } \\
\text { tourism }\end{array}$ & $\mathrm{Y}^{*}$ & $\begin{array}{l}\text { Detailed regulations to exclude commercial fishing from most of } \\
\text { SBMP and manage recreational fishing, but concerns remain } \\
\text { about potential for overexploitation of some stocks, particularly } \\
\text { pink snapper. Detailed regulations to manage other marine } \\
\text { wildlife tourism activities, particularly dolphin watching. }\end{array}$ \\
\hline $\begin{array}{l}\text { 5. Promoting green } \\
\text { marketing }\end{array}$ & $Y$ & $\begin{array}{l}\text { SBMP marketed as premium ecotourism destination, including } \\
\text { through its recognition as a WHS that is effectively protected. }\end{array}$ \\
\hline $\begin{array}{l}\text { 6. Promoting } \\
\text { diversified and } \\
\text { supplementary } \\
\text { livelihoods }\end{array}$ & $\mathrm{Y}^{*}$ & $\begin{array}{l}\text { Marine wildlife tourism in SBMP is relatively under-developed } \\
\text { and there is scope to expand, including to reduce reliance on } \\
\text { recreational fishing and thereby reduce pressure on stocks }\end{array}$ \\
\hline $\begin{array}{l}\text { 9. Provision of state } \\
\text { funding }\end{array}$ & $Y^{*}$ & $\begin{array}{l}\text { Fisheries Division and PaWS are reasonably well funded but this } \\
\text { could be less short-term to enable strategic approach and } \\
\text { specific MPA funding is needed for Fisheries Division. }\end{array}$ \\
\hline $\begin{array}{l}\text { 10. Provision of NGO, } \\
\text { Private Sector and } \\
\text { user fee funding }\end{array}$ & Y & $\begin{array}{l}\text { Entrance fees to watch dolphins and fishing licence fees support } \\
\text { monitoring and research. Industry and NGO funding also } \\
\text { supports research. }\end{array}$ \\
\hline$\frac{\text { Communication }}{11 . \text { Raising awareness }}$ & $Y$ & $\begin{array}{l}\text { Extensive use of leaflets, signs, web sites, officer briefings, PaWS } \\
\text { interpretation facilities, etc. to raise awareness of the ecological } \\
\text { values of SBMP. }\end{array}$ \\
\hline $\begin{array}{l}\text { 12. Promoting } \\
\text { recognition of benefits }\end{array}$ & Y & $\begin{array}{l}\text { Focus in awareness raising of importance of restrictions to } \\
\text { promote sustainability. }\end{array}$ \\
\hline $\begin{array}{l}\text { 13. Promoting } \\
\text { recognition of } \\
\text { regulations and } \\
\text { restrictions }\end{array}$ & $Y$ & $\begin{array}{l}\text { Extensive use of leaflets, signage, web sites, officer briefings, etc. } \\
\text { to promote recognition of regulations and restrictions, including } \\
\text { a smartphone app for recreational fishers. }\end{array}$ \\
\hline $\begin{array}{l}\text { Knowledge } \\
\text { 14. Promoting } \\
\text { collective learning }\end{array}$ & $Y$ & $\begin{array}{l}\text { Collaborations between scientists, regulators, recreational } \\
\text { fishers, marine wildlife tourism operators and tourists to gather } \\
\text { data, funded by state and industries. Customary knowledge } \\
\text { amongst indigenous aboriginal Australians drawn on. }\end{array}$ \\
\hline $\begin{array}{l}\text { 16. Independent } \\
\text { advice and arbitration }\end{array}$ & $Y$ & $\begin{array}{l}\text { Commonwealth and industry funded research provides advisory } \\
\text { role and World Heritage Committees provide some arbitration } \\
\text { roles. }\end{array}$ \\
\hline $\begin{array}{l}\text { Legal } \\
\begin{array}{l}\text { 17. Hierarchical } \\
\text { obligations }\end{array}\end{array}$ & $Y$ & $\begin{array}{l}\text { Obligations under World Heritage Convention, commonwealth } \\
\text { and state legislation. }\end{array}$ \\
\hline
\end{tabular}




\begin{tabular}{|c|c|c|}
\hline $\begin{array}{l}\text { 18. Capacity for } \\
\text { enforcement }\end{array}$ & $Y^{*}$ & $\begin{array}{l}\text { Officers patrol by vehicle, boat, air and foot but scope for } \\
\text { improved enforcement of sanctuary zones, including dedicated } \\
\text { funding for Fisheries Division enforcement activities. }\end{array}$ \\
\hline $\begin{array}{l}\text { 19. Penalties for } \\
\text { deterrence }\end{array}$ & $\mathrm{Y}^{*}$ & $\begin{array}{l}\text { Large penalties can be imposed but tendency for Fisheries } \\
\text { Division to issue smaller fixed penalty fines, rather than pursuing } \\
\text { larger penalties through prosecutions in court, undermines } \\
\text { deterrence. }\end{array}$ \\
\hline $\begin{array}{l}\text { 21. Attaching } \\
\text { conditions to use and } \\
\text { property rights, } \\
\text { decentralisation, etc }\end{array}$ & Y & $\begin{array}{l}\text { Strict requirements for marine wildlife tour vessels and } \\
\text { recreational fishing charter vessels to comply with licence } \\
\text { conditions related to MPA conservation measures. }\end{array}$ \\
\hline $\begin{array}{l}\text { 22. Cross-jurisdictional } \\
\text { coordination }\end{array}$ & $\mathrm{Y}^{*}$ & $\begin{array}{l}\text { Legal obligations for other sectoral regulators to exercise their } \\
\text { functions to promote achievement of SBMP objectives; } \\
\text { collaboration and cross-authorisation between Fisheries Division } \\
\text { and PaWS officers but coordination could be improved, } \\
\text { particularly regarding penalties for deterrence (I-19). Scope for } \\
\text { Division for Agriculture and Food to promote land management } \\
\text { practices on sheep stations to minimise sediment run-off during } \\
\text { heavy rain events to reduce seagrass smothering. }\end{array}$ \\
\hline $\begin{array}{l}\text { 23. Clear and } \\
\text { consistent legal } \\
\text { definitions }\end{array}$ & $Y$ & $\begin{array}{l}\text { Clear and consistent definitions between commonwealth and } \\
\text { state legislation and related sectoral legislation. }\end{array}$ \\
\hline $\begin{array}{l}\text { 25. Legal adjudication } \\
\text { platforms }\end{array}$ & $Y$ & $\begin{array}{l}\text { Cases can be appealed to state and commonwealth courts and } \\
\text { UNESCO World Heritage Committee provides an adjudication } \\
\text { role. }\end{array}$ \\
\hline $\begin{array}{l}\text { 26. Transparency, } \\
\text { accountability and } \\
\text { fairness }\end{array}$ & $Y$ & $\begin{array}{l}\text { Broad scale reports publicly available and further information } \\
\text { was eventually provided when requested. }\end{array}$ \\
\hline $\begin{array}{l}\text { Participation } \\
\text { 27. Rules for } \\
\text { Participation }\end{array}$ & Y & $\begin{array}{l}\text { Clear rules for user participation on Shark Bay World Heritage } \\
\text { Advisory Committee. }\end{array}$ \\
\hline $\begin{array}{l}\text { 28. Establishing } \\
\text { collaborative } \\
\text { platforms }\end{array}$ & $Y$ & $\begin{array}{l}\text { Shark Bay World Heritage Advisory Committee provides for } \\
\text { participation of representatives of sectoral user groups. }\end{array}$ \\
\hline $\begin{array}{l}\text { 31. Decentralising } \\
\text { responsibilities }\end{array}$ & $Y$ & $\begin{array}{l}\text { Some commonwealth responsibilities decentralised to state } \\
\text { authorities, particularly for fisheries and parks \& wildlife. }\end{array}$ \\
\hline 32. Peer enforcement & $Y$ & $\begin{array}{l}\text { Recreational fishers can encourage peer compliance and report } \\
\text { infringements. Marine wildlife tourism operators provide mutual } \\
\text { surveillance role, partly as a result of competition for licences. }\end{array}$ \\
\hline $\begin{array}{l}\text { 33. Building trust and } \\
\text { the capacity for } \\
\text { cooperation }\end{array}$ & $Y$ & $\begin{array}{l}\text { Shark Bay World Heritage Advisory Committee promotes this, as } \\
\text { do contacts and discussions between officers and various users. }\end{array}$ \\
\hline $\begin{array}{l}\text { 34. Building linkages } \\
\text { between relevant } \\
\text { authorities and user } \\
\text { representatives }\end{array}$ & Y & $\begin{array}{l}\text { Key user representatives appointed to Shark Bay World Heritage } \\
\text { Advisory Committee }\end{array}$ \\
\hline
\end{tabular}




\begin{tabular}{|l|l|l|}
\hline $\begin{array}{l}\text { 35. Building on local } \\
\text { customs }\end{array}$ & $Y$ & $\begin{array}{l}\text { Indigenous aboriginal Australian practices are provided for and } \\
\text { their knowledge is drawn on, with approaches being developed } \\
\text { for joint management, including the recruitment of several } \\
\text { indigenous trainee rangers. }\end{array}$ \\
\hline $\begin{array}{l}\text { 36. Potential to } \\
\text { influence higher } \\
\text { institutional levels }\end{array}$ & $\mathrm{Y}$ & $\begin{array}{l}\text { Shark Bay World Heritage Advisory Committee can influence } \\
\text { state, commonwealth and even international decisions, latter by } \\
\text { UNESCO World Heritage Committee. }\end{array}$ \\
\hline
\end{tabular}

Table 6 Incentives applied in Shark Bay Marine Park

Incentives applied $(\mathrm{Y})$, including those that are particularly important priorities for strengthening $\left(\mathrm{Y}^{*}\right)$ and introducing $\left(\mathrm{N}^{*}\right)$ (Detailed version - Supplementary Material, Table 2)

\section{Discussions}

Overall, these two MPAs employ a relatively high diversity of incentives (NMP 27, SBMP 26, former includes I-15) from a total of 36 incentives in the MPAG framework, being in the top quintile amongst the 50 MPAG case studies undertaken to date, based on the number of incentives each uses. Effectiveness in both case studies is undermined by the proximal impacts of recreational fishing, commercial fishing being completely banned throughout all of NMP and most of SBMP. In both case studies a relatively high diversity of incentives are combined and interact with each other (Figure 3). These combinations are particularly important to better manage recreational fishing through a compulsory licencing scheme for all recreational fishers, sanctuary zones, bag limits, minimum landing sizes, technical measures, fillet export limits, total allowable catches (though uptake cannot feasibly be monitored), etc., making them amongst the most sophisticated and detailed recreational fisheries management frameworks in the world.

These combinations are also effective at managing marine wildlife watching activities, the impacts being mitigated through a diversity of incentives. For example, focusing on the management of whale shark watching in NMP, it is clear that a governance framework has evolved over the last 20+ years, with state agencies and regulations playing a key role, along with partnerships with other actors, including private operators and scientific researchers. A diversity of incentives interact and mutually support each other, as is discussed below, and whilst it has taken many years for this framework to evolve and develop, elements of it, including particular combinations of incentives, can be adapted and applied to marine wildlife tourism operations in other relevant MPAs. This is provided for through the recognition of the effectiveness of the governance framework for whale shark watching in NMP as world leading good practice, reflected through the numerous invitations to NMP's whale shark officer to give presentations on this governance framework at conferences around the world, coupled with capacity-building exchange visits. Indeed, one of the aims of the MPAG project [4] that this case study is an element of is to deconstruct and facilitate the dissemination of such world-leading good practice through analyses of how such incentives interact to promote effectiveness and equity. 


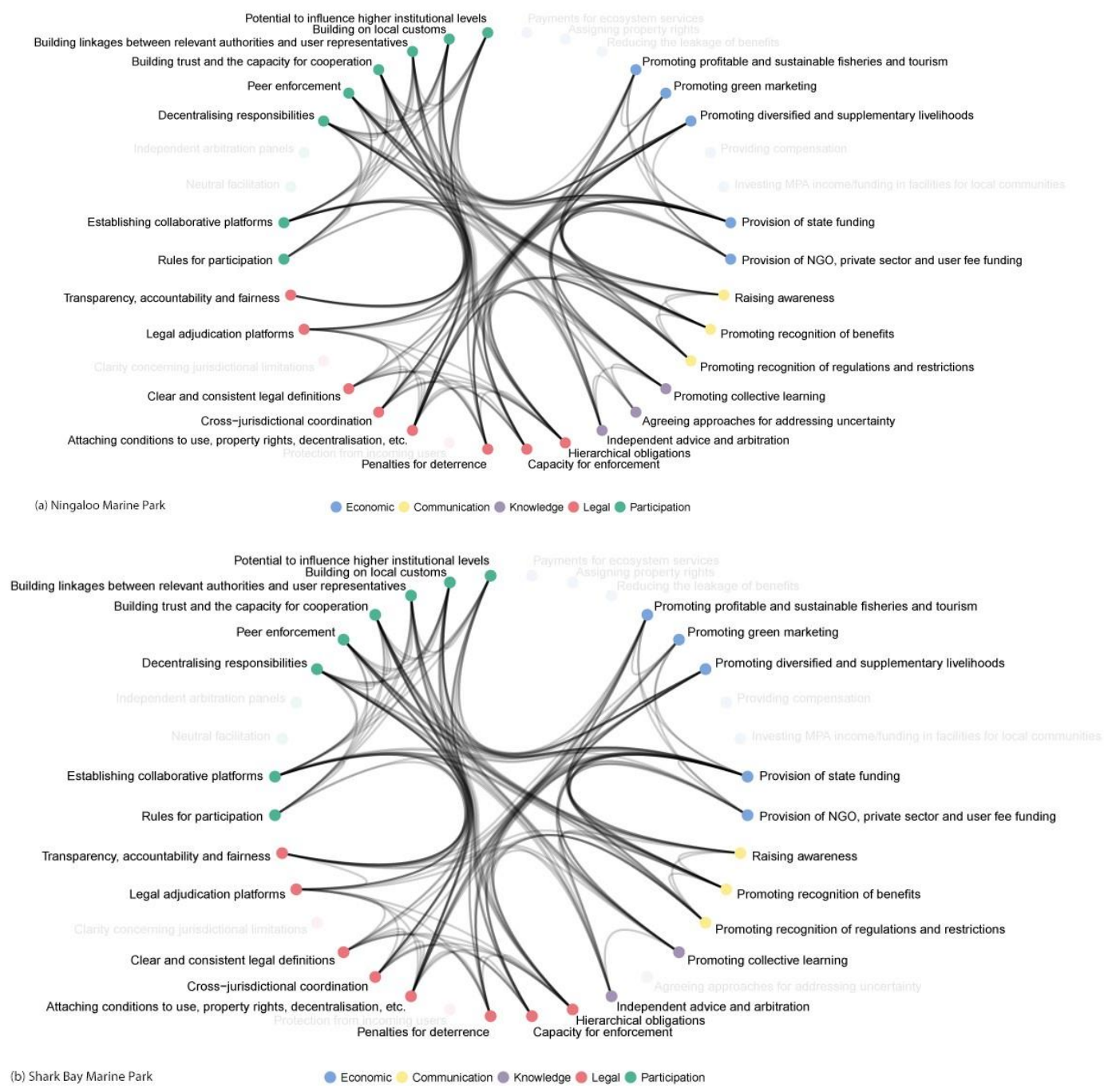

Figure 3 Interactions between incentives to promote the effective and equitable governance of whale shark watching in (a) Ningaloo Marine Park and (b) Shark Bay Marine Park

The whale shark watching sector is described above, including an overview of the approaches to managing this activity. These approaches can be deconstructed in more detail using the incentives structure (Table 5), with a focus on how incentives interact and mutually support each other, i.e. particular elements of the interactions illustrated in Figure 3(a). A limited number of licenses are issued to operate tourism vessels for snorkelling with whale sharks, and this minimises the disturbance to whale sharks. Cooperation amongst operators limits the number of whale shark encounters as they restrict interactions through creating a broader whole day tour package, priced above a specific level agreed amongst operators, including other activities that do not involve encounters with whale sharks. This serves to promote profitable and sustainable tourism (I-4) and promote diversified and supplementary livelihoods (I-6), but many other combinations of incentives are also involved (note that numbers in brackets (I-xx) after incentive descriptions refer to the incentive numbers in Table 5, which are themselves based on the numbered taxonomy of all 36 incentives [5]). There are strict and clearly defined regulations (I-23) in place on how the activities are undertaken, including legal conditions attached (I-21) to the whale shark watching vessel licences through the statutory code of conduct, and vessel operators watch each other with the potential to support peer enforcement (I-32) actions through competition for licences, building trust and cooperation (I33) amongst the operators, authorities and the surrounding community. It is the responsibility of each 
operator to raise the awareness (I-11) of tourists on the vessels of the conservation importance of the whale sharks, to promote recognition of the regulations and restrictions (I-13) when watching whales sharks and of the benefits for conservation (I-12) of cooperating with them, in particular regarding behaviour and activities by snorkellers that should be followed or avoided. This also serves to promote green marketing (I-5) as whale shark watching is publicised as marine conservation-friendly and supportive 'ecotourism' to attract visitors. As this area is popular with whale shark aggregations they are considered as a feature of 'outstanding universal value' (OUV) under the Ningaloo Coast World Heritage Site listing, placing hierarchical obligations (I-17) to ensure whale shark watching does not undermine these values. This also encourages state funding (I-9), adequate capacity for enforcement (I-18) and sufficient penalties for deterrence (I-19) that help to ensure the regulations are upheld. The legal obligations under the WHC for this program include a requirement to report annually on the status of these whale shark aggregations, and also to include relevant research and monitoring findings in order to support adaptive management, which encourages collective learning (I-14) amongst tour operators, management authorities and scientists, which is also financially supported by the user fees (I-10). Such integrated combinations of interacting and mutually supportive incentives provide for the need to protect the conservation features of 'outstanding universal value' under the World Heritage Convention that both marine parks support, combined with the need to provide vital economic development opportunities for the people of these remote towns. The governance of whale shark watching in NMP represents world-leading good practice in achieving this balance through a high diversity of interacting incentives, in keeping with previous findings that NMP represents good practice in terms of combining top-down, economic and participative governance approaches for promoting effective sharkbased ecotourism [46].

\begin{tabular}{|l|l|l|}
\hline $\begin{array}{l}\text { Incentives that are particularly } \\
\text { important priorities for } \\
\text { strengthening }\end{array}$ & Ningaloo Marine Park (NMP) & Shark Bay Marine Park (SBMP) \\
\hline $\begin{array}{l}\text { 4. Promoting profitable and } \\
\text { sustainable fishing and tourism }\end{array}$ & $\begin{array}{l}\text { Concerns remain in both parks about the sustainability of certain } \\
\text { stocks in face of recreational fishing pressure, as it is extremely } \\
\text { challenging to assess and limit recreational fishing effort in order } \\
\text { to implement TACs; also some concerns about impacts of } \\
\text { marine wildlife encounters by unlicensed vessels }\end{array}$ \\
\hline $\begin{array}{l}\text { 6. Promoting diversified and } \\
\text { supplementary livelihoods }\end{array}$ & $\begin{array}{l}\text { Potential to promote the } \\
\text { expansion of non-extractive } \\
\text { marine wildlife tourism }\end{array}$ & $\begin{array}{l}\text { No need for strengthening was } \\
\text { raised }\end{array}$ \\
\hline 9. Provision of state funding & $\begin{array}{l}\text { Need for longer term funding } \\
\text { commitments for strategic } \\
\text { planning }\end{array}$ & $\begin{array}{l}\text { Need for dedicated MPA } \\
\text { funding for Fisheries Division; } \\
\text { also need for longer term } \\
\text { funding commitments for } \\
\text { strategic planning }\end{array}$ \\
\hline $\begin{array}{l}\text { 14. Promoting collective } \\
\text { learning }\end{array}$ & $\begin{array}{l}\text { Residents would value } \\
\text { opportunity for participative } \\
\text { research programme [45] }\end{array}$ & $\begin{array}{l}\text { No need for strengthening was } \\
\text { raised }\end{array}$ \\
\hline 18. Capacity for enforcement & $\begin{array}{l}\text { Need improved enforcement } \\
\text { of sanctuary zones }\end{array}$ & $\begin{array}{l}\text { Need improved enforcement } \\
\text { of sanctuary zones, including } \\
\text { dedicated funding for Fisheries } \\
\text { Division for enforcement of } \\
\text { these in SBMP }\end{array}$ \\
\hline 19. Penalties for deterrence & $\begin{array}{l}\text { Tendency for Fisheries Division to apply fixed penalties, for } \\
\text { which fines are relatively low, undermines deterrence capacity. } \\
\text { Need to pursue prosecutions in some cases, for which fines and }\end{array}$ \\
\hline
\end{tabular}




\begin{tabular}{|l|l|l|}
\hline & $\begin{array}{l}\text { other sanctions are larger, to provide a stronger deterrence to } \\
\text { others }\end{array}$ \\
\hline $\begin{array}{l}\text { 22. Cross-jurisdictional } \\
\text { coordination }\end{array}$ & $\begin{array}{l}\text { Need for improved coordination between Fisheries Division and } \\
\text { PaWS, particularly regarding penalties for deterrence (I-19 } \\
\text { above) }\end{array}$ \\
\hline $\begin{array}{l}\text { 26. Transparency, } \\
\text { accountability and fairness }\end{array}$ & $\begin{array}{l}\text { Need for research and } \\
\text { monitoring findings on NMP to } \\
\text { be made more available }\end{array}$ & $\begin{array}{l}\text { No needs raised in relation to } \\
\text { these four incentives }\end{array}$ \\
\cline { 1 - 2 } $\begin{array}{l}\text { 28. Establishing collaborative } \\
\text { platforms }\end{array}$ & $\begin{array}{l}\text { Need to address tensions with } \\
\text { some representatives of } \\
\text { recreational fishing sector by } \\
\text { building linkages to provide for } \\
\text { their specific representation } \\
\text { for cooperation }\end{array}$ & \\
\cline { 1 - 2 } $\begin{array}{l}\text { 34. Building linkages between } \\
\text { relevant authority and user } \\
\text { representatives }\end{array}$ & $\begin{array}{l}\text { trust and capacity for } \\
\text { cooperation. }\end{array}$ \\
\hline
\end{tabular}

Table 7 Incentives considered as particularly important priorities for strengthening in Ningaloo (9) and Shark Bay (6) Marine Parks

There are, however, some key weaknesses in these frameworks (Table 7), particularly related to the degree of integration and cooperation between the agencies with responsibilities for fisheries management (Fisheries Division) and biodiversity conservation (PaWS) within these MPAs. There are some strong measures in place to promote such cross-jurisdictional integration and cooperation (I-22), including formal collaborative operational plans and the cross-authorisation of officers, whereby they can enforce each other's regulations, but some underlying tensions between the two agencies were indicated during interviews. The Fisheries Division are mainly focused on promoting the sustainable exploitation of fish stocks across the wider seascape, whereas PaWS take both a seascape approach for ecosystems, habitats and species and a narrower approach focused on specific zones in specific marine parks for particular habitats and species. Unless specific resources are made available to the Fisheries Division to enforce marine park and sanctuary zone restrictions (noting that these extra resources are available for NMP but not for SBMP), they are inclined to prioritise monitoring and enforcement activities at a wider spatial scale, with much less of a focus on the narrower spatial scale of marine parks and the sanctuary zones within them.

This is arguably a reflection of underlying tensions [47] between the more utilitarian ethical perspective of the Fisheries Division in their focus on the sustainable exploitation of fish stocks, and the more ecocentric and preservationist ethical perspectives of PaWS in their focus on the conservation of ecosystems, habitats and species. These tensions are particularly apparent at the stage where recreational fishermen who breach sanctuary zone and other restrictions (bag limits, fillet export limits, etc) in the marine parks are being prosecuted. All such infringements are dealt with by the Fisheries Division as they are fishing offences under an order of the Fish Resources Management Act (1994), but they allegedly tend to apply relatively low fixed penalties in the vast majority of cases, rather than allocating officer time and related resources to pursue prosecutions in court, which can lead to much higher fines and other sanctions. Some argued that such fixed penalty fines were too low to provide sufficient deterrence (I-19) and that this, coupled with a lack of capacity for enforcement (I-18), especially given the remote location of many sanctuary zones, meant that many recreational fishers accepted the risk of detection and were prepared to poach in sanctuary zones, the non-compliance discussed above [14] supporting this view. This is undermining the effectiveness of such zones and wider restrictions in sustaining and restoring populations of recreationally exploited fish, particularly spangled emperor (NMP) stocks.

Whilst monitoring has revealed that there were more and/or larger spangled emperor inside NMP's sanctuary zones [16, pp.25] so they would still appear to be effective in providing a degree of protection, the 
tendency for the Fisheries Division to more often rely on fixed penalties would appear to be undermining the deterrence of potential recreational fishing poachers in sanctuary zones, and thereby of the potential of these zones to contribute to the conservation and restoration of these recreationally fished stocks. This is an example of the importance of cross-jurisdictional coordination (I-22).

Other challenges that tables 5, 6 and 7 illustrate include the scope for more transparency in making the findings of research and monitoring available, especially given that such transparency helps promote collective learning (I-14) and build trust and the capacity for cooperation (I-33), recognising that a lack of transparency is a hurdle to adaptive collaborative management. There is also more scope to promote diversified and supplementary livelihoods (I-6), particularly in SBMP, where there is still considerable potential to develop and promote marine wildlife watching, such as humpback whale watching and snorkelling in sheltered coves, as a non-extractive commercial tourism activity, providing an alternative to extractive recreational fishing and thereby potentially reducing pressure on recreationally fished stocks. Whilst this potential has been more fully capitalised on in NMP, SBMP remains focused mainly on recreational fishing, along with watching provisioned dolphins in Monkey Mia, and the wider area has further potential for marine wildlife tourism to be developed.

There also seems to be an issue with a lack of a representative specifically of the recreational fishing community (I-28), particularly in NMP, where pressure on stocks from recreational fishing is a particular issue. There were clearly some tensions between representatives of the recreational fishing sector and NMP representatives, these having occasionally led to animosity and threats, and whilst there might be challenges in seeking a recreational fishing representative who could both constructively engage with the Ningaloo Coast World Heritage Advisory Committee (NCWHAC) and retain the trust and support of their sector, i.e. able to address the challenges of being a boundary spanner [48], the building of linkages between relevant authorities and this key user sector (1-34) is argued to be a priority in order to help address recreational fishing issues through the promotion of collective learning (1-14) and the building of trust and capacity for cooperation (I-33). This may also be the case in Shark Bay but it was not feasible to find a representative of the recreational fishing sector to interview there, though no other interviewees mentioned such tensions.

The tensions between the recreational fishing sector and the NCWHAC are not consistent with apparent levels of support for no-take sanctuary zones, Navarro et al. [49] reporting that $88.7 \%$ of 107 recreational fishers surveyed at launch points in NMP in 2017 supported such zones (higher than average 63.3\% support across all 10 marine parks surveyed in Australia) and $92.5 \%$ believed that environmental benefits were occurring (higher than average $74.5 \%$ belief across all 10 marine parks surveyed), though only $7.5 \%$ had perceived that the no-take sanctuary zones benefited their fishing, with $70.1 \%$ perceiving no change and $22.4 \%$ perceiving negative impacts on fishing (compared with $9.7 \%, 58.1 \%$ and $32.2 \%$ respectively across all 10 marine parks surveyed). Such figures indicate that whilst the majority of recreational fishers that visit NMP support no-take sanctuary zones and believe that they are delivering environmental benefits, they have not yet actually perceived benefits for their fishing, possibly because of the ineffectiveness of the notake sanctuary zones, this being in turn partly because a significant proportion of recreational fishers have been seen to be poaching in such zones, i.e. $8-12 \%$ boat fishers and $2-4 \%$ of shore-based fishers [14], though these may represent those who do not support or believe in such zones.

These figures also indicate that the tensions between the recreational fishers sector and NMP advocates reported by the single representative of this sector interviewed at NMP and by several members of the NCWHAC may not be consistent with the views of the wider constituency, the reported hostility of some fishers clearly not being representative of the wider sector. A subsequent survey of recreational fishers across Western Australia similarly indicated that across all three sub-sectors only $\sim 13 \%$ oppose marine sanctuaries and that the "influential minority have a disproportional impact on policy" [50]. It may therefore be feasible to seek a recreational fishing sector representative who is more typical of the wider views of this sector, as the tensions between this sector and the NMP may simply be down to an unrepresentative but 
vocal minority. These figures similarly indicate that the critical views of the NGO RecFishWest on the benefits of no-take sanctuary zones that they discussed during an interview may not be representative of the wider recreational fishing sector.

There are many other ways in which NGOs are involved in the governance of these marine parks. Several NGOs actively advocate for more effective conservation e.g. Australian Marine Conservation Society and Conservation Council of WA ran the 'Save Ningaloo Reef' campaign 2000-2005 and are still active through the Protect Ningaloo campaign [51], and some have a more direct role, e.g. Ningaloo Turtle Program [52] run by the Cape Conservation Group (local NGO) [53] in collaboration with PaWS. Several NGOs actively advocate for more effective conservation of Shark Bay Marine Park and Bush Heritage Australia have a more direct role through the acquisition of riparian lands, e.g. Hamelin Station [54], including run-off management initiatives (ditch management, reduced grazing) to reduce smothering of seagrass during typhoons. Pew Charitable Trusts also advocate for the involvement of indigenous aboriginal Australians in marine park management, in collaboration with the federal government/PaWS under the Indigenous Ranger and Indigenous Protected Area (IPA) programs [55]. These case studies are thus illustrative of the wide range of roles that NGOs can play in governance [4, pp.108-109], from advocating for specific user groups, i.e. recreational fishers, with questions as to whether RecFishWest's resistance to no-take sanctuaries is actually representative of the majority of their constituents, through to campaigning for better conservation, promoting collective learning amongst local people, regulators and scientists, purchasing and running properties to promote better conservation, and promoting the rights and active involvement of indigenous people.

Equity would appear not to be a significant issue in Shark Bay, as indigenous aboriginal Australians' (IAAs') customary practices are provided for, including access to strict nature reserve zones from which other people are excluded, and the right to hunt a small number of green turtles, dugongs, etc. in Shark Bay, under Indigenous Land Use Agreements (ILUAs). Related traditional knowledge and skills are drawn on, for example, in the monitoring of dugongs, through employing IAAs as seasonal rangers, i.e. collective learning (I-14), under the Federal Government's Indigenous Ranger and Indigenous Protected Area (IPA) programs [55]. Whilst Native Title has been granted to IAAs for other parks in Australia, e.g. Murujuga National Park in Burup, Western Australia, in keeping with federal recognition of native land rights, granting legal management rights to IAAs which they exercise in partnership with government agencies, IAAs discussed that they were satisfied with the current Joint Management Planning arrangements. Native title is being pursued for an area covering most of SBMP and all of NMP under the Gnulli claim through a very long legal process instigated in 1997, but there were some concerns that this was being pushed for by IAAs that now live outside the area in Perth, Geraldton, etc. and that these IAA representatives do not necessarily represent the views and interests of IAAs who still live in the Shark Bay area. In NMP, on the other hand, there were still some evident tensions between some IAA representatives and some sheep station operators, with evidence of still simmering resentment at the historical taking of land from IAAs. Against this backdrop, the taking of portions of lands from some pastoral leases in 2015 to be run, along with some unallocated Crown Land adjacent to NMP, as Nyinggulu (Ningaloo) coastal reserves, is leading to resentment from some sheep station operators. The new reserves will be co-managed with IAAs through a joint management plan that was being consulted on in 2019, including the recruitment of indigenous trainee rangers (1-35), and this will help address some historical inequity issues noted above, whilst providing for the conservation and compatible recreational use of these adjacent coastal reserve areas.

\section{Conclusions}

Whilst there are incentives that could be strengthened (Tables 5, 6 and 7), both of these MPAs employ a relatively high diversity of incentives with relatively few considered as being in need of strengthening (NMP 9, SBMP 6) and no apparent gaps in the incentives framework that need addressing through the introduction of extra incentives. Both case studies illustrate how recreational fishing can place very significant pressures 
on stocks that can lead to them being overfished, highlighting the importance and impacts of this often neglected sector [56], though both case studies are also 'good practice' examples of a highly evolved regulatory frameworks for recreational fisheries. They are also 'good practice' examples of a highly evolved regulatory frameworks for marine wildlife tourism, particularly for whale shark watching in NMP and dolphin watching in SBMP, the former, in particular, arguably representing a world-leading example of 'good practice'. However, despite the high effectiveness in addressing local proximal impacts, in the long-term the ecosystems of both MPAs are threatened by the already emerging impacts of climate change, particularly on coral reefs in NMP and on seagrass beds in SBMP.

Whilst protection from proximal impacts can help in promoting the resilience of these ecosystems, the widescale distal impacts of climate change are already impacting both MPAs and their long-term protection can only be ensured through the mitigation of climate change. There is clearly nothing significant that can be done at a marine park governance level to mitigate climate change, other than employ the related impacts on these iconic WHSs as symbols of the importance of climate change mitigation at national and global scales. Whilst the minimisation of proximal impacts, e.g. damage to seagrass and coral reef habitats, depletion of fish populations through recreational overfishing, etc., may help promote the resilience of these ecosystems to climate change impacts, e.g. by promoting the health of coral reefs [4], such proximal protection appears to have been ineffective in protecting sanctuary zones from bleaching in the Great Barrier Reef Marine Park [2, 3]. The vulnerability of these iconic marine ecosystems, including the seagrass beds, must, therefore, also be employed as a rallying cry to mitigate climate change at a global scale, e.g. the World Heritage Committee have 'strongly invited' all countries to undertake the most ambitious implementation of the Paris Agreement to mitigate climate change in order to protect World Heritage coral reefs from the potentially devastating impacts of bleaching [57].

As with most if not all MPAs, protection from proximal impacts can promote their effectiveness and help build resilience to climate change, both MPAs representing 'good practice' examples in this respect, elements of which could potentially be adapted and transferred to other MPAs, but in the longer-term their conservation can only realistically be achieved by addressing the distal impacts of climate change through global measures to mitigate this. Proximal protection can improve the prospects in the short-term, providing a buffer against the already emerging impacts of climate change, but such protection will arguably be of little effectiveness in the longer-term unless the distal impacts of climate change are mitigated. A diversity of incentives evidently can promote resilience in the short-term [4], but in the longer-term the implementation of global action to mitigate climate change is the only way to promote the resilience of marine ecosystems, including those of Ningaloo and Shark Bay.

\section{Funding}

This research was supported by an academic funding allocation from the Faculty of Social and Historical Sciences, University College London (UCL).

\section{Declarations of interest}

None.

\section{Acknowledgements}

I am very grateful to all the interviewees as their rich perspectives were vital to this research, and to the Parks and Wildlife Service and Fisheries Division Officers who provided much information to support it. I am particularly grateful to Peter Barnes (Ningaloo Marine Park Coordinator) and Cheryl Cowell (Shark Bay World Heritage Committee Project Officer), both of the Parks and Wildlife Service, who played a particularly important role in supporting my field research and making me feel welcome. This paper is dedicated to the memories of my father, John Jones, and brother, Andrew Jones, who died during the course of this research. 


\section{References}

[1] J.C Day, K Dobbs, Effective governance of a large and complex cross-jurisdictional marine protected area: Australia's Great Barrier Reef, Marine Policy 41 (2013) 14-24, http://dx.doi.org/10.1016/j.marpol.2012.12.020

[2] T.P. Hughes et al., Coral reefs in the Anthropocene, Nature 546 (2017) 82-90, https://dx.doi.org/10.1038/nature22901

[3] T.P.Hughes et al., Global warming impairs stock-recruitment dynamics of corals, Nature 568 (2019) 387390, https://doi.org/10.1038/s41586-019-1081-y

[4] P.J.S. Jones, Governing Marine Protected Areas - resilience through diversity, Earthscan/Routledge, 2014, https://www.routledge.com/products/9781138679238. Also see www.mpag.info

[5] Jones and Long - This issue.

[6] Central Intelligence Agency, The World Fact Book: Australia, https://www.cia.gov/library/publications/the-world-factbook/geos/as.html (Accessed 29 June 2018). [7] World Bank, Worldwide Governance Indicators, www.govindicators.org (Accessed 29 June 2018). [8] United Nations Development Programme, Human Development Indicators: Australia, http://hdr.undp.org/en/countries/profiles/AUS (Accessed 30 June 2018).

[9] Government of Western Australia, Department of Jobs, Tourism, Science and Innovation, Economic Profile, https://www.jtsi.wa.gov.au/economic-development/economy/economic-profile (Accessed 30 April 2019).

[10] Marine Parks and Reserves Authority (MPRA) and the Department of Conservation and Land Management (CALM), Management Plan for the Ningaloo Marine Park and Muiron Islands Marine Management Area 2005-2015, https://www.dpaw.wa.gov.au/images/documents/parks/managementplans/decarchive/ningaloo_mp_01_2005_withmaps.pdf (Accessed 30 April 2019).

[11] National Parks and Nature Conservation Authority, Western Australia, Shark Bay Marine Reserves Management Plan 1996-2006, Management plan (Department of Conservation and Land Management) no. 34, 1996.

[12] Department of Primary Industries and Regional Development, Recreational Fishing Guides, http://www.fish.wa.gov.au/About-Us/Publications/Recreational-Fishing/Pages/Recreational-FishingGuides.aspx (Accessed 4 April 2019).

[13] R.D. Pillans et al., Multi Year Observations Reveal Variability in Residence of a Tropical Demersal Fish, Lethrinus nebulosus: Implications for Spatial Management, PLoS ONE 9(9): e105507, 2014, https://dx.doi.org/10.1371/journal.pone.0105507

[14] C.B Smallwood, L.E. Beckley, Spatial distribution and zoning compliance of recreational fishing in Ningaloo Marine Park, north-western Australia, Fisheries Research 125-126 (2012) 40-50, https://dx.doi.org/10.1016/j.fishres.2012.01.019

[15] A.K.Cresswell et al., Disentangling the response of fishes to recreational fishing over 30 years within a fringing coral reef reserve network, Biological Conservation 237 (2019) 514-524, https://doi.org/10.1016/j.biocon.2019.06.023

[16] Western Australian Marine Science Institution (2016) Node 3: Managing and Conserving the Marine Estate Final Summary Report, www.wamsi.org.au/sites/wamsi.org.au/files/WAMSI\%20Node\%203\%20Final\%20Summary\%20Report.pdf [17] D.J. Gaughan, K. Santoro, K. (eds), Status Reports of the Fisheries and Aquatic Resources of Western Australia 2016/17, Fisheries Division, Department of Primary Industries and Regional Development, 2018. www.fish.wa.gov.au/Documents/sofar/status_reports_of_the_fisheries_and_aquatic_resources_201617.pdf

[18] Fisheries Division, Department of Primary Industries and Regional Development, Gascoyne demersal scalefish resource harvest strategy 2017 - 2021, Fisheries Management Paper No. 284, 2017, http://www.fish.wa.gov.au/Documents/management_papers/fmp284.pdf 
[19] Fisheries Division, Department of Primary Industries and Regional Development, Shark Bay pink snapper recovery in focus, http://www.fish.wa.gov.au/Species/Pink-Snapper/Pages/Shark-Bay-pink-snapper-

recovery-in-focus.aspx (Accessed 2 November 2018).

[20] G. Jackson, M. Moran, Recovery of inner Shark Bay snapper (Pagrus auratus) stocks: relevant research and adaptive recreational fisheries management in a World Heritage Property, Marine and Freshwater Research 63 (2012) 1180-1191, https://doi.org/10.1071/MF12091

[21] G. Jackson et al., Assessing the effectiveness of harvest tags in the management of a small-scale, iconic marine recreational fishery in Western Australia, ICES Journal of Marine Science 73 (2016) 2666-2676, https://doi.org/10.1093/icesjms/fsw093

[22] J.P. Copping et al., Does bathymetry drive coastal whale shark (Rhincodon typus) aggregations? PeerJ. 6, e4904, 2018, https://dx.doi.org/10.7717/peerj.4904

[23] S.J. Pierce, B. Norman, Rhincodon typus. The IUCN Red List of Threatened Species, eT19488A2365291, 2016, http://dx.doi.org/10.2305/IUCN.UK.2016-1.RLTS.T19488A2365291.en

[24] H. Raudino et al., Whale shark behavioural responses to tourism interactions in Ningaloo Marine Park and implications for future management. Conservation Science W. Aust 10:2 (2016)

https://www.dpaw.wa.gov.au/images/documents/conservation-management/forests/forest-

produce/conservation_science_10.2_final.pdf

[25] R. Mau, Managing for Conservation and Recreation: The Ningaloo Whale Shark Experience, Journal of Ecotourism 7:2-3 (2008) 213-225, https://doi.org/10.1080/14724040802140550

[26] R.L. Sanzogni, M.G. Meekan, J.J. Meeuwig, Multi-Year Impacts of Ecotourism on Whale Shark (Rhincodon typus) Visitation at Ningaloo Reef, Western Australia. PLoS ONE 10(9), e0127345, 2015,

https://doi.org/10.1371/journal.pone.0127345

[27] Department of Parks and Wildlife, Whale shark management with particular reference to Ningaloo Marine Park, Wildlife management program no. 57, 2013,

https://www.dpaw.wa.gov.au/images/documents/conservation-

management/marine/20130277_Whale_Shark_management_-_Ningaloo_FINAL_small.pdf

[28] V. Foroughirad, J. Mann, Long-term impacts of fish provisioning on the behavior and survival of wild bottlenose dolphins, Biological Conservation 160 (2013) 242-249,

https://doi.org/10.1016/j.biocon.2013.01.001

[29] J. Mann, C. Kemps, The effects of provisioning on maternal care in bottlenose dolphins. In: N. Gales, M.

Hindell, R. Kirkwood (eds.) Marine Mammals and Humans: Towards a sustainable balance. CSIRO Publishing, 2003.

[30] C. Bulbeck, Facing the Wild: Ecotourism, Conservation and Animal Encounters, London: Earthscan, 2005.

[31] Money Mia. www.sharkbay.org/place/monkey-mia (Accessed 5 January 2019).

[32] Learmonth Bundle Site. www.epa.wa.gov.au/proposals/learmonth-bundle-site (Accessed 23 March 2019).

[33] Perth Now - Author Tim Winton joins battle over proposed oil and gas facility conservationists fear could threaten Ningaloo Reef. www.perthnow.com.au/news/pilbara-news/conservationists-fear-new-oil-and-gasfacility-in-exmouth-could-threaten-ningaloo-reef-ng-b88989747z (Accessed 23 March 2019).

[34] The Guardian, Exmouth split over pipeline factory proposed for gulf that supports Ningaloo Reef. www.theguardian.com/australia-news/2018/oct/14/exmouth-split-over-pipeline-factory-proposed-for-gulfthat-supports-ningaloo-reef (Accessed 23 March 2019).

[35] J.A. Thompson et al., Extreme temperatures, foundation species, and abrupt ecosystem change: an example from an iconic seagrass ecosystem, Global Change Biology 21 (2014) 1463-1474, https://dx.doi.org/10.1111/gcb.12694

[36] J.A.Y. Moore et al., Unprecedented Mass Bleaching and Loss of Coral across $12^{\circ}$ of Latitude in Western Australia in 2010-11, PLoS ONE 7(12): e51807, 2012, https://dx.doi.org/10.1371/journal.pone.0051807

[37] R. Nowicki et al., Indirect legacy effects if an extreme climate event on a marine megafaunal community, Ecological Monographs e01365 (in press), https://doi.org/10.1002/ecm.1365

[38] A. Arias-Oritz et al., A marine heatwave drives massive losses from the world's largest seagrass carbon stocks, Nature Climate Change 8 (2018) 338-344, https://doi.org/10.1038/s41558-018-0096-y

25

Jones PJS (in press) A governance analysis of Ningaloo and Shark Bay Marine Parks, Western Australia: putting the 'eco' in tourism to build resilience but threatened in long-term by climate change? Marine Policy, 103636.

https://doi.org/10.1016/j.marpol.2019.103636. One of 18 papers in a special section on 26 case studies on MPA Governance 
[39] R.J. Nowicki et al., Predicting seagrass recovery times and their implications following an extreme climate event, Mar. Ecol. Prog. Ser. 567 (2017) 79-93, https://doi.org/10.3354/meps12029

[40] Shark Bay World Heritage Advisory Committee. https://www.sharkbay.org/world-heritage/managingworld-heritage-area/shark-bay-world-heritage-advisory-committee (Accessed 9 May 2019) [41] National Environmental Science Programme (2018) Climate change and the Shark Bay World Heritage Area: Foundations for a climate change adaptation strategy and action plan, Earth Systems and Climate Change Hub Report No. 7. http://nespclimate.com.au/wp-content/uploads/2016/03/SBWHA-CC-workshopreport.pdf (Accessed 9 May 2019)

[42] Ningaloo Coast World Heritage Advisory Committee.

https://www.dpaw.wa.gov.au/management/world-heritage-areas/510-ningaloo-coast-world-heritageadvisory-committee (Accessed 9 May 20019)

[43] C.T. Perry et al., Loss of coral reef growth capacity to track future increases in sea level, Nature 558 (2018) 396-400, https://doi.org/10.1038/s41586-018-0194-z

[44] R. Albright et al., Reversal of ocean acidification enhances net coral reef calcification, Nature 531 (2016) 362-365, https://dx.doi.org/10.1038/nature17155

[45] C. Cvitanovich et al., Building trust among marine protected area managers and community members through scientific research: Insights from the Ningaloo Marine Park, Australia, Marine Policy 93 (2018) 195206, https://doi.org/10.1016/j.marpol.2018.04.010

[46] E.J. Techera, Klein N, The role of law in shark-based eco-tourism: Lessons from Australia, Marine Policy 39(2013) 21-28, http://dx.doi.org/10.1016/j.marpol.2012.10.003

[47] P.J.S. Jones, Point of View - Arguments for conventional fisheries management and against no-take marine protected areas: only half of the story? Reviews in Fish Biology and Fisheries 17 (2007) 31-43, http://dx.doi.org/10.1007/s11160-006-9016-8

[48] T.R. Johnson, Fishermen, Scientists, and Boundary Spanners: Cooperative Research in the U.S. Illex Squid Fishery, Society \& Natural Resources, $24: 3$ (2011) 242-255, http://dx.doi.org/10.1080/08941920802545800

[49] M. Navarro et al., Recreational fishers' support for no-take marine reserves is high and increases with reserve age, Marine Policy 96 (2018) 44-52, https://doi.org/10.1016/j.marpol.2018.06.021

[50] A. McNeill et al., Specialised recreational fishers reject sanctuary zones and favour fisheries

Management, Marine Policy 107 (2019) 103592, https://doi.org/10.1016/j.marpol.2019.103592

[51] Protect Ningaloo Campaign, www.protectningaloo.org.au (Accessed 27 March 2019).

[52] Ningaloo Turtle Program, www.ningalooturtles.org.au (Accessed 27 March 2019).

[53] Cape Conservation Group, ccg.org.au (Accessed 27 March 2019).

[54] Hamelin, www.bushheritage.org.au/places-we-protect/western-australia/hamelin (Accessed 27 March 2019).

[55] B. Traill, Pew Trusts, Indigenous Programs Benefit Australians but Could Do More With Increased Funding, https://www.pewtrusts.org/en/research-and-analysis/articles/2017/02/03/indigenous-programsbenefit-australians-but-could-do-more-with-increased-funding (Accessed 27 March 2019).

[56] R. Arlinghaus et al., Governing the recreational dimension of global fisheries, PNAS 116 (2019) 52095213, https://doi.org/10.1073/pnas.1902796116

[57] World Heritage Committee 2017, Decisions adopted during the forty-first session of the World Heritage Committee (Krakow, 2017), pp. 10-11. WHC/17/41.COM/18. http://whc.unesco.org/archive/2017/whc1741com-18-en.pdf (Accessed 8 March 2019) 


\section{Supplementary material}

Supplementary Table 1 - Ningaloo Marine Park - Incentives applied $(\mathrm{Y})$, including those that are particularly important priorities for strengthening $\left(\mathrm{Y}^{*}\right)$ and introducing $\left(\mathrm{N}^{*}\right)$

\begin{tabular}{|c|c|c|}
\hline Incentive type & Used & How/Why \\
\hline $\begin{array}{l}\text { Economic } \\
\text { 4. Promoting profitable } \\
\text { and sustainable fishing } \\
\text { and tourism }\end{array}$ & $\mathrm{Y}^{*}$ & $\begin{array}{l}\text { Regulatory framework to exclude commercial fishing from } \\
\text { majority of park and sustainably manage recreational fishing, } \\
\text { including very detailed restrictions [12], such as sanctuary } \\
\text { zones ( } 33.4 \% \text { of NMP), bag limits, size limits, technical } \\
\text { measures, fillet export limits, etc. Detailed regulations to } \\
\text { manage recreational fishing, but concerns remain about } \\
\text { effectiveness of sanctuary zones and the potential for } \\
\text { overexploitation of some stocks, particularly spangled } \\
\text { emperor. Recreational fishing TAC uptake not actually } \\
\text { monitored or restricted and concerns remain that some stocks } \\
\text { are over-exploited by recreational fishing. Whale shark } \\
\text { watching operators cooperate on keeping prices at set level } \\
\text { and minimising/managing whale shark encounters to avoid } \\
\text { impacts and have a detailed Code of Conduct to minimise } \\
\text { disturbance: world leading example of good practice but } \\
\text { concerns remain about impacts of unlicensed casual whale } \\
\text { shark encounters [27] }\end{array}$ \\
\hline $\begin{array}{l}\text { 5. Promoting green } \\
\text { marketing }\end{array}$ & $Y$ & $\begin{array}{l}\text { NMP is marketed as a premium ecotourism destination for } \\
\text { sustainable marine wildlife tourism, including through its WHS } \\
\text { listing. All the fisheries in the state of Western Australia are } \\
\text { pursuing MSC accreditation }{ }^{1} \text {, and the Exmouth Gulf prawn } \\
\text { fishery }{ }^{2} \text { is one of the first to have been successfully certified in } \\
\text { the present program }\end{array}$ \\
\hline $\begin{array}{l}\text { 6. Promoting diversified } \\
\text { and supplementary } \\
\text { livelihoods }\end{array}$ & $Y$ & $\begin{array}{l}\text { Marine wildlife tourism, particularly whale shark and manta ray } \\
\text { watching, provides an important alternative to economic } \\
\text { reliance on extractive recreational fishing, thereby reducing } \\
\text { pressures on stocks. Recruitment of trainee indigenous rangers } \\
\text { has created employment opportunities for otherwise } \\
\text { marginalised indigenous aboriginal Australians. }\end{array}$ \\
\hline $\begin{array}{l}\text { 9. Provision of state } \\
\text { funding }\end{array}$ & $\mathrm{Y}^{*}$ & $\begin{array}{l}\text { The Fisheries Division and PaWS are reasonably well funded, } \\
\text { including budget allocations for the MPA, but these could be } \\
\text { less short-term to enable strategic long-term programmes. } \\
\text { State and commonwealth funding for research to inform and } \\
\text { evaluate management. }\end{array}$ \\
\hline $\begin{array}{l}\text { 10. Provision of NGO, } \\
\text { Private Sector and user } \\
\text { fee funding }\end{array}$ & $Y$ & $\begin{array}{l}\text { Whale shark watching fees (AUS\$18 adult) are charged by } \\
\text { operators on behalf of PaWS, as part of the total cost of day } \\
\text { tours, to support the management and conservation of whale } \\
\text { sharks, including administrative support, education, training, } \\
\text { compliance, enforcement, research and monitoring. } \\
\text { Recreational fishing licence fees partly allocated to research to } \\
\text { support MPA management, alongside corporate and NGO } \\
\text { funded research and funding for other projects, including }\end{array}$ \\
\hline
\end{tabular}

${ }^{1}$ http://www.fish.wa.gov.au/Fishing-and-Aquaculture/Third-party-sustainability-certification/Pages/default.aspx

${ }^{2}$ http://www.fish.wa.gov.au/Fishing-and-Aquaculture/Third-party-sustainability-certification/Pages/Prawn.aspx 


\begin{tabular}{|c|c|c|}
\hline & & $\begin{array}{l}\text { short-term funding for MPA related projects through the } \\
\text { Royalties for Regions scheme, whereby royalties to state from } \\
\text { mining and offshore petroleum are re-invested in rural } \\
\text { development projects; Ningaloo Outlook Programme }{ }^{3} \text { part- } \\
\text { funded by mining/oil company. }\end{array}$ \\
\hline$\frac{\text { Communication }}{11 . \text { Raising awareness }}$ & $\mathrm{Y}$ & $\begin{array}{l}\text { Extensive use of leaflets, signage, web sites, officers, briefings, } \\
\text { PaWS interpretation facilities, etc. to raise awareness of the } \\
\text { ecological values of the MPA but there could be a more } \\
\text { strategic approach to this between the Fisheries Division and } \\
\text { PaWS. The Ningaloo Centre }{ }^{4} \text { in Exmouth has extensive } \\
\text { awareness-raising displays, including on the marine life of } \\
\text { NMP, e.g. aquarium, visitor galleries, etc. }\end{array}$ \\
\hline $\begin{array}{l}\text { 12. Promoting } \\
\text { recognition of benefits }\end{array}$ & $\mathrm{Y}$ & $\begin{array}{l}\text { Focus in awareness raising of importance of restrictions to } \\
\text { promote sustainability }\end{array}$ \\
\hline $\begin{array}{l}\text { 13. Promoting } \\
\text { recognition of } \\
\text { regulations and } \\
\text { restrictions }\end{array}$ & $Y$ & $\begin{array}{l}\text { Extensive use of leaflets, signage, web sites, officer briefings, } \\
\text { etc. to promote recognition of regulations and restrictions, } \\
\text { including a smartphone app developed by PaWS for } \\
\text { recreational fishers that will give location specific details of } \\
\text { zonal restrictions, etc. }\end{array}$ \\
\hline $\begin{array}{l}\text { Knowledge } \\
\begin{array}{l}\text { 14. Promoting collective } \\
\text { learning }\end{array}\end{array}$ & $\mathrm{Y}^{*}$ & $\begin{array}{l}\text { Collaborations between scientists, regulators and recreational } \\
\text { fishers to gather relevant information and data, e.g. Ningaloo } \\
\text { Outlook Programme }{ }^{3} \text { funded by mining/oil company and } \\
\text { commonwealth (CSIRO); whale shark watching tourists and } \\
\text { operators provide photos for population assessments; e.g. fish } \\
\text { frames project }{ }^{5} \text { : recreational fishers send filleted remains of } \\
\text { fish to Fisheries Division to assist in data gathering for stock } \\
\text { assessments; FishWatch program }{ }^{6} \text { provides for the reporting of } \\
\text { aquatic pests and diseases; some recreational fishers keep fish } \\
\text { diaries and feedback information by phone surveys. Many } \\
\text { residents would value the opportunity to participate in } \\
\text { research to inform the management of NMP, including "the } \\
\text { establishment of community-based programmes in which they } \\
\text { can actively participate" to draw on their knowledge and help } \\
\text { build trust [45] }\end{array}$ \\
\hline $\begin{array}{l}\text { 15. Agreeing } \\
\text { approaches for } \\
\text { addressing uncertainty }\end{array}$ & $Y$ & $\begin{array}{l}\text { Particularly with regards to the regulation of whale shark } \\
\text { watching, "evidence of any impacts is difficult to obtain and } \\
\text { interpret and for this reason a precautionary approach to } \\
\text { management will continue to be adopted" [27]. The expansion } \\
\text { of the sanctuary zones to } 33.4 \% \text { and studies of them could also } \\
\text { be considered to represent a precautionary approach. }\end{array}$ \\
\hline $\begin{array}{l}\text { 16. Independent advice } \\
\text { and arbitration }\end{array}$ & $Y$ & $\begin{array}{l}\text { Commonwealth and industry funded research programmes } \\
\text { help inform management decisions but do not provide an } \\
\text { arbitration role; local World Heritage Advisory Committee and } \\
\text { international World Heritage Committee provides some } \\
\text { scientific arbitration roles }\end{array}$ \\
\hline
\end{tabular}

${ }^{3}$ https://research.csiro.au/ningaloo/

${ }^{4}$ https://www.ningaloocentre.com.au/the-ningaloo-centre/

${ }^{5}$ http://www.fish.wa.gov.au/frames

${ }^{6}$ http://www.fish.wa.gov.au/About-Us/Contact-Us/Pages/Fish-watch.aspx 


\begin{tabular}{|c|c|c|}
\hline $\begin{array}{l}\text { Legal } \\
\begin{array}{l}\text { 17. Hierarchical } \\
\text { obligations }\end{array}\end{array}$ & $Y$ & $\begin{array}{l}\text { Legal obligations under World Heritage Convention, } \\
\text { commonwealth and state legislation }\end{array}$ \\
\hline $\begin{array}{l}\text { 18. Capacity for } \\
\text { enforcement }\end{array}$ & $Y^{*}$ & $\begin{array}{l}\text { Officers patrol by vehicle, boat, plane and foot to promote } \\
\text { compliance, but need for improved enforcement of sanctuary } \\
\text { restrictions. Electronic monitoring system (EMS) with GPS } \\
\text { automatically records and reports whale shark watching } \\
\text { locations \& activities to monitor compliance [27] }\end{array}$ \\
\hline $\begin{array}{l}\text { 19. Penalties for } \\
\text { deterrence }\end{array}$ & $\mathrm{Y}^{*}$ & $\begin{array}{l}\text { Large fines can be imposed for breaching NMP restrictions but } \\
\text { deterrence is undermined by the tendency for the Fisheries } \\
\text { Division to apply lower fixed penalties for recreational fishing } \\
\text { offences in NMP rather than going to expense and effort of } \\
\text { pursuing court prosecutions undermines deterrence, } \\
\text { sometimes to the frustration of PaW officers. Particular need } \\
\text { for Fisheries Division to pursue prosecutions to provide } \\
\text { stronger deterrence. }\end{array}$ \\
\hline $\begin{array}{l}\text { 21. Attaching conditions } \\
\text { to use and property } \\
\text { rights, decentralisation, } \\
\text { etc }\end{array}$ & $Y$ & $\begin{array}{l}\text { Strict requirements for marine wildlife tour vessels and } \\
\text { recreational fishing charter vessels to comply with licence } \\
\text { conditions related to MPA conservation measures, including } \\
\text { conditions for whale shark watching detailed in the statutory } \\
\text { Code of Conduct, under the Wildlife Conservation (Close } \\
\text { Season for Whale Sharks) Notice (1996) }\end{array}$ \\
\hline $\begin{array}{l}\text { 22. Cross-jurisdictional } \\
\text { coordination }\end{array}$ & $\mathrm{Y}^{*}$ & $\begin{array}{l}\text { Other sectoral regulators, particularly the EPA for oil, are } \\
\text { obliged under Conservation and Land Management (CALM) \& } \\
\text { Environmental Protection and Biodiversity Conservation (EPBC) } \\
\text { Acts to exercise their functions to promote achievement of } \\
\text { NMP objectives. Coordination between PaWS and the Fisheries } \\
\text { Division promoted through Collaborative Operational Plans and } \\
\text { cross authorisation to enforce each other's regulations but } \\
\text { need for improved coordination, particularly regarding } \\
\text { penalties for deterrence (I-19). }\end{array}$ \\
\hline $\begin{array}{l}\text { 23. Clear and consistent } \\
\text { legal definitions }\end{array}$ & $Y$ & $\begin{array}{l}\text { Clear and consistent definitions between commonwealth and } \\
\text { state legislation and related sectoral legislation }\end{array}$ \\
\hline $\begin{array}{l}\text { 25. Legal adjudication } \\
\text { platforms }\end{array}$ & $Y$ & $\begin{array}{l}\text { Cases can be appealed to state and commonwealth courts and } \\
\text { international World Heritage Committee can provide a legal } \\
\text { adjudication role }\end{array}$ \\
\hline $\begin{array}{l}\text { 26. Transparency, } \\
\text { accountability and } \\
\text { fairness }\end{array}$ & $Y^{*}$ & $\begin{array}{l}\text { There are broad scale reports of condition of NMP but the } \\
\text { detailed data underlying them is not publicly available. Data } \\
\text { sets can be applied for but challenging to eventually gain } \\
\text { access to the data. Need for monitoring and research findings } \\
\text { to be made more openly available as lack of transparency is a } \\
\text { hurdle to adaptive collaborative management: restricts } \\
\text { capacity to discuss impacts, pressures and proposals to address } \\
\text { with local people. Local people "would like to know more } \\
\text { about the scientific research undertaken in the marine park, } \\
\text { and would like local marine park managers to communicate } \\
\text { the results of scientific research undertaken in the NMP more } \\
\text { effectively" [45] }\end{array}$ \\
\hline Participation & $Y$ & $\begin{array}{l}\text { Clear rules for user participation on Ningaloo Coast World } \\
\text { Heritage Advisory Committee }\end{array}$ \\
\hline
\end{tabular}




\begin{tabular}{|c|c|c|}
\hline $\begin{array}{l}\text { 27. Rules for } \\
\text { Participation }\end{array}$ & & \\
\hline $\begin{array}{l}\text { 28. Establishing } \\
\text { collaborative platforms }\end{array}$ & $\mathrm{Y}^{*}$ & $\begin{array}{l}\text { Ningaloo Coast World Heritage Advisory Committee [42] } \\
\text { provides for participation of representatives of sectoral user } \\
\text { groups, though the recreational fishing sector is not specifically } \\
\text { represented and there is a particular need for this sector to be } \\
\text { specifically represented }\end{array}$ \\
\hline $\begin{array}{l}\text { 31. Decentralising } \\
\text { responsibilities }\end{array}$ & $Y$ & $\begin{array}{l}\text { Some commonwealth responsibilities decentralised to state } \\
\text { authorities, particularly for fisheries and parks \& wildlife }\end{array}$ \\
\hline 32. Peer enforcement & $Y$ & $\begin{array}{l}\text { Some recreational fishers encourage peer compliance and can } \\
\text { anonymously report infringements via the Fishwatch }{ }^{6} \text { hotline. } \\
\text { Marine wildlife tourism operators provide mutual surveillance } \\
\text { role, partly as a result of competition for licences. }\end{array}$ \\
\hline $\begin{array}{l}\text { 33. Building trust and } \\
\text { the capacity for } \\
\text { cooperation }\end{array}$ & $\mathrm{Y}^{*}$ & $\begin{array}{l}\text { Ningaloo Coast World Heritage Advisory Committee promotes } \\
\text { this, as do contacts and discussions between officers and } \\
\text { various users, but there are some tensions with the } \\
\text { recreational fishing sector. Participative research that includes } \\
\text { community-based programmes II-14) could help build trust } \\
\text { amongst the wider community [45] }\end{array}$ \\
\hline $\begin{array}{l}\text { 34. Building linkages } \\
\text { between relevant } \\
\text { authorities and user } \\
\text { representatives }\end{array}$ & $\mathrm{Y}^{*}$ & $\begin{array}{l}\text { Key user representatives are officially appointed to the } \\
\text { Ningaloo Coast World Heritage Advisory Committee but } \\
\text { development of links with specific recreational fishing } \\
\text { representatives could help address tensions }\end{array}$ \\
\hline $\begin{array}{l}\text { 35. Building on local } \\
\text { customs }\end{array}$ & $\mathrm{Y}$ & $\begin{array}{l}\text { Indigenous aboriginal Australian practices are provided for and } \\
\text { their knowledge is drawn on, with approaches being developed } \\
\text { for joint management between Indigenous aboriginal } \\
\text { Australians and relevant authorities under the Indigenous } \\
\text { Ranger and Indigenous Protected Area (IPA) programs [55] } \\
\text { (Pew Charitable Trusts in collaboration with PaWS) and } \\
\text { Indigenous Land Use Agreements (ILUAs), including the } \\
\text { recruitment of several indigenous trainee rangers. }\end{array}$ \\
\hline $\begin{array}{l}\text { 36. Potential to } \\
\text { influence higher } \\
\text { institutional levels }\end{array}$ & $Y$ & $\begin{array}{l}\text { Deliberations and decisions by Ningaloo Coast World Heritage } \\
\text { Advisory Committee and related advice can have significant } \\
\text { influence on state, commonwealth and even international } \\
\text { decisions by UNESCO World Heritage Committee under World } \\
\text { Heritage Convention }\end{array}$ \\
\hline
\end{tabular}

Supplementary Table 2 - Shark Bay Marine Park - Incentives applied (Y), including those that are particularly important priorities for strengthening $\left(\mathrm{Y}^{*}\right)$ and introducing $\left(\mathrm{N}^{*}\right)$

\begin{tabular}{|l|l|l|}
\hline Incentive type & Used & How/Why \\
\hline $\begin{array}{l}\text { Economic } \\
\text { 4. Promoting } \\
\text { profitable and } \\
\text { sustainable fishing and } \\
\text { tourism }\end{array}$ & $\mathrm{Y}^{*}$ & $\begin{array}{l}\text { Regulatory framework to manage a few (6 active licences) } \\
\text { commercial fishers in General Use or Special Purpose Areas, } \\
\text { including TACs (e.g. pink snapper bycatch TAC 2 te, recreational } \\
\text { fishing TAC 35 te), and sustainably manage recreational fishing, } \\
\text { including very detailed restrictions [12], such as sanctuary zones } \\
\text { (17.6\% SBMP), bag limits, size limits, technical measures, fillet } \\
\text { export limits, etc. Recreational fishing TAC uptake not directly } \\
\text { monitored or restricted and concerns remain that some stocks }\end{array}$ \\
\hline
\end{tabular}




\begin{tabular}{|c|c|c|}
\hline & & $\begin{array}{l}\text { are over-exploited by recreational fishing. Detailed regulations } \\
\text { to manage other marine wildlife tourism activities, particularly } \\
\text { dolphin watching, to minimise impacts on species and habitats. }\end{array}$ \\
\hline $\begin{array}{l}\text { 5. Promoting green } \\
\text { marketing }\end{array}$ & $Y$ & $\begin{array}{l}\text { SBMP is marketed as a premium ecotourism destination for } \\
\text { sustainable marine wildlife tourism, including through its } \\
\text { recognition as a WHS that is effectively protected. All the } \\
\text { fisheries in the WA state are pursuing MSC accreditation } \\
\text { the and } \\
\text { successfully certified in the present program, though this is not } \\
\text { directly related to SBMP. }\end{array}$ \\
\hline $\begin{array}{l}\text { 6. Promoting } \\
\text { diversified and } \\
\text { supplementary } \\
\text { livelihoods }\end{array}$ & $Y^{*}$ & $\begin{array}{l}\text { Scope to expand marine wildlife tourism and thereby diversify } \\
\text { tourism economy could be better promoted, providing an } \\
\text { alternative to economic reliance on extractive recreational } \\
\text { fishing and thereby reducing pressures on stocks }\end{array}$ \\
\hline $\begin{array}{l}\text { 9. Provision of state } \\
\text { funding }\end{array}$ & $\mathrm{Y}^{*}$ & $\begin{array}{l}\text { The Fisheries Division and PaWs are reasonably well funded, } \\
\text { including budget allocations for the MPA, but these could be less } \\
\text { short-term to enable strategic long-term programmes and there } \\
\text { is a need for MPA dedicated enforcement, research and } \\
\text { monitoring funding for the Fisheries Division. State and } \\
\text { commonwealth funding for research to inform and evaluate } \\
\text { management. }\end{array}$ \\
\hline $\begin{array}{l}\text { 10. Provision of NGO, } \\
\text { Private Sector and } \\
\text { user fee funding }\end{array}$ & $Y$ & $\begin{array}{l}\text { Recreational fishing licence fees and Monkey Mia entrance fees } \\
\text { (AUS\$12 adults) contribute to officer costs and funding for } \\
\text { research to support MPA management, alongside corporate and } \\
\text { NGO funded research. Short-term funding for MPA related } \\
\text { projects is provided through the Royalties for Regions scheme, } \\
\text { whereby royalties to state from mining and offshore petroleum } \\
\text { are re-invested in rural development projects }\end{array}$ \\
\hline$\frac{\text { Communication }}{11 . \text { Raising awareness }}$ & $Y$ & $\begin{array}{l}\text { Extensive use of leaflets, signage, web sites, officer briefings, } \\
\text { PaWS interpretation facilities, etc. to raise awareness of the } \\
\text { ecological values of the MPA but there could be a more strategic } \\
\text { approach to this between the Fisheries Division and PaWS }\end{array}$ \\
\hline $\begin{array}{l}\text { 12. Promoting } \\
\text { recognition of benefits }\end{array}$ & $Y$ & $\begin{array}{l}\text { Focus in awareness raising of importance of restrictions to } \\
\text { promote sustainability }\end{array}$ \\
\hline $\begin{array}{l}\text { 13. Promoting } \\
\text { recognition of } \\
\text { regulations and } \\
\text { restrictions }\end{array}$ & $Y$ & $\begin{array}{l}\text { Extensive use of leaflets, signage, web sites, officers, briefings, } \\
\text { etc. to promote recognition of regulations/restrictions, including } \\
\text { smartphone app. being developed by the Fisheries Division for } \\
\text { recreational fishers, which will give location specific details of } \\
\text { zonal restrictions, etc. }\end{array}$ \\
\hline $\begin{array}{l}\text { Knowledge } \\
\text { 14. Promoting } \\
\text { collective learning }\end{array}$ & $Y$ & $\begin{array}{l}\text { Collaborations between scientists, regulators, recreational } \\
\text { fishers, marine wildlife tourism operators and tourists to gather } \\
\text { relevant information and data, e.g. fish frames }{ }^{9} \text { project: } \\
\text { recreational fishers send filleted remains of fish to Fisheries } \\
\text { Division to assist in data gathering for stock assessments; } \\
\text { FishWatch program }{ }^{10} \text { provides for the reporting of aquatic pests } \\
\text { and diseases; some recreational fishers keep fish diaries and }\end{array}$ \\
\hline
\end{tabular}

\footnotetext{
${ }^{7}$ http://www.fish.wa.gov.au/Fishing-and-Aquaculture/Third-party-sustainability-certification/Pages/default.aspx

${ }^{8} \mathrm{http} / / /$ www.fish.wa.gov.au/Fishing-and-Aquaculture/Third-party-sustainability-certification/Pages/Prawn.aspx

${ }^{9}$ http://www.fish.wa.gov.au/frames

${ }^{10} \mathrm{http}: / /$ www.fish.wa.gov.au/About-Us/Contact-Us/Pages/Fish-watch.aspx
} 


\begin{tabular}{|c|c|c|}
\hline & & $\begin{array}{l}\text { feedback information by phone surveys; drawing on customary } \\
\text { knowledge, particularly in dugong tracking and capture for } \\
\text { research, through collaborations between PaWS and indigenous } \\
\text { aboriginal Australians }\end{array}$ \\
\hline $\begin{array}{l}\text { 16. Independent } \\
\text { advice and arbitration }\end{array}$ & $Y$ & $\begin{array}{l}\text { Commonwealth funded research programmes help inform } \\
\text { management decisions but do not provide an arbitration role; } \\
\text { local World Heritage Advisory Committee and UNESCO World } \\
\text { Heritage Committee provide some scientific arbitration roles }\end{array}$ \\
\hline $\begin{array}{l}\text { Legal } \\
\text { 17. Hierarchical } \\
\text { obligations }\end{array}$ & $Y$ & $\begin{array}{l}\text { Legal obligations under World Heritage Convention, } \\
\text { commonwealth and state legislation }\end{array}$ \\
\hline $\begin{array}{l}\text { 18. Capacity for } \\
\text { enforcement }\end{array}$ & $\mathrm{Y}^{*}$ & $\begin{array}{l}\text { Officers patrol by vehicle, boat, air and foot to promote } \\
\text { compliance, but scope for improved enforcement of sanctuary } \\
\text { restrictions, including dedicated MPA enforcement funding for } \\
\text { the Fisheries Division }\end{array}$ \\
\hline $\begin{array}{l}\text { 19. Penalties for } \\
\text { deterrence }\end{array}$ & $\mathrm{Y}^{*}$ & $\begin{array}{l}\text { Large fines can be imposed for breaching MPA restrictions but } \\
\text { tendency for the Fisheries Division to apply lower fixed penalties } \\
\text { for recreational fishing offences in MPAs rather than going to } \\
\text { expense and effort of pursuing court prosecutions undermines } \\
\text { deterrence. Particular need for Fisheries Division to pursue } \\
\text { prosecutions to provide stronger deterrence. }\end{array}$ \\
\hline $\begin{array}{l}\text { 21. Attaching } \\
\text { conditions to use and } \\
\text { property rights }\end{array}$ & $Y$ & $\begin{array}{l}\text { Strict requirements for marine wildlife tour vessels and } \\
\text { recreational fishing boats to comply with licence conditions } \\
\text { related to MPA conservation measures }\end{array}$ \\
\hline $\begin{array}{l}\text { 22. Cross-jurisdictional } \\
\text { coordination }\end{array}$ & $\mathrm{Y}^{*}$ & $\begin{array}{l}\text { Other sectoral regulators are obliged to comply with MPA } \\
\text { conditions; coordination between the Fisheries Division and } \\
\text { PaWS promoted through Collaborative Operational Plans but } \\
\text { need for improved coordination, particularly regarding penalties } \\
\text { for deterrence. Scope for improved coordination between PaWS } \\
\text { and the Division for Agriculture and Food to address riparian } \\
\text { land management issues on sheep stations in order to reduce } \\
\text { sediment-laden run-off during heavy rain events to reduce } \\
\text { seagrass smothering. }\end{array}$ \\
\hline $\begin{array}{l}\text { 23. Clear and } \\
\text { consistent legal } \\
\text { definitions }\end{array}$ & $Y$ & $\begin{array}{l}\text { Clear and consistent definitions between commonwealth and } \\
\text { state legislation and related sectoral legislation }\end{array}$ \\
\hline $\begin{array}{l}\text { 25. Legal adjudication } \\
\text { platforms }\end{array}$ & $Y$ & $\begin{array}{l}\text { Cases can be appealed to state and commonwealth courts and } \\
\text { UNESCO World Heritage Committee provides a legal } \\
\text { adjudication role }\end{array}$ \\
\hline $\begin{array}{l}\text { 26. Transparency, } \\
\text { accountability and } \\
\text { fairness }\end{array}$ & $Y$ & $\begin{array}{l}\text { There are broad scale reports of condition of SBMP and further } \\
\text { information was eventually provided when requested, though it } \\
\text { was a particular challenge to gain pink snapper stock monitoring } \\
\text { data from the central Fisheries Division. }\end{array}$ \\
\hline $\begin{array}{l}\text { Participation } \\
\text { 27. Rules for } \\
\text { Participation }\end{array}$ & $Y$ & $\begin{array}{l}\text { Clear rules for user participation on Shark Bay World Heritage } \\
\text { Advisory Committee. }\end{array}$ \\
\hline $\begin{array}{l}\text { 28. Establishing } \\
\text { collaborative } \\
\text { platforms }\end{array}$ & $Y$ & $\begin{array}{l}\text { Shark Bay World Heritage Advisory Committee [40] provides for } \\
\text { participation of representatives of sectoral user groups }\end{array}$ \\
\hline
\end{tabular}




\begin{tabular}{|l|l|l|}
\hline $\begin{array}{l}\text { 31. Decentralising } \\
\text { responsibilities }\end{array}$ & $\mathrm{Y}$ & $\begin{array}{l}\text { Some commonwealth responsibilities decentralised to state } \\
\text { authorities, particularly for fisheries and parks \& wildlife }\end{array}$ \\
\hline 32. Peer enforcement & $\mathrm{Y}$ & $\begin{array}{l}\text { Some recreational fishers encourage peer compliance and can } \\
\text { report infringements to Fishwatch }{ }^{11} \text { hotline. Marine wildlife } \\
\text { tourism operators provide mutual surveillance role, partly as a } \\
\text { result of keen competition for licences coupled with intense } \\
\text { rivalry between them. }\end{array}$ \\
\hline $\begin{array}{l}\text { 33. Building trust and } \\
\text { the capacity for } \\
\text { cooperation }\end{array}$ & $\mathrm{Y}$ & $\begin{array}{l}\text { Shark Bay World Heritage Advisory Committee promotes this, as } \\
\text { do contacts and discussions between officers and various users }\end{array}$ \\
\hline $\begin{array}{l}\text { 34. Building linkages } \\
\text { between relevant } \\
\text { authorities and user } \\
\text { representatives }\end{array}$ & $\mathrm{Y}$ & $\begin{array}{l}\text { Key user representatives are officially appointed to the Shark Bay } \\
\text { World Heritage Advisory Committee }\end{array}$ \\
\hline $\begin{array}{l}\text { 35. Building on local } \\
\text { customs }\end{array}$ & $\mathrm{Y}$ & $\begin{array}{l}\text { Indigenous aboriginal Australian practices are provided for and } \\
\text { their knowledge is drawn on, with approaches being developed } \\
\text { for joint management between Indigenous aboriginal Australians } \\
\text { and relevant authorities, under Indigenous Ranger and } \\
\text { Indigenous Protected Area (IPA) programs [55] }\end{array}$ \\
\hline $\begin{array}{l}\text { 36. Potential to } \\
\text { influence higher } \\
\text { institutional levels }\end{array}$ & $\mathrm{Y}$ & $\begin{array}{l}\text { Deliberations and decisions by local Shark Bay World Heritage } \\
\text { Advisory Committee and related advice can have significant } \\
\text { influence on state, commonwealth and even international } \\
\text { decisions by UNESCO World Heritage Committee }\end{array}$ \\
\hline
\end{tabular}

${ }^{11}$ http://www.fish.wa.gov.au/About-Us/Contact-Us/Pages/Fish-watch.aspx 